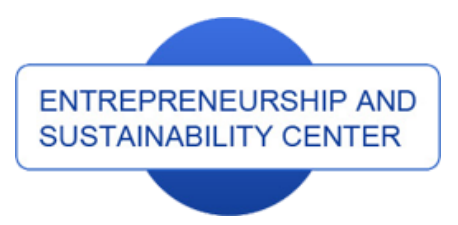

Publisher

http://jssidoi.org/esc/home enterprise

europe

network

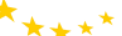

Business Support on Your Doorstep

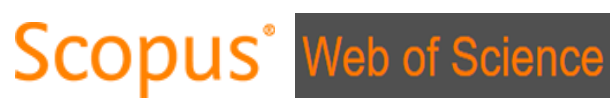

\title{
LOW-LOW (LL) HIGH HUMAN CAPITAL CLUSTERS IN PUBLIC ADMINISTRATION EMPLOYMENT - PREDICTOR FOR DIGITAL INFRASTRUCTURE PUBLIC INVESTMENT PRIORITY - ROMANIA CASE STUDY*
}

\author{
Cristina Lincaru' ${ }^{1}$, Speranta Pîrciog ${ }^{2}$, Adriana Grigorescu ${ }^{3}$, Gabriela Tudose ${ }^{4}$ \\ ${ }^{1,2,4}$ National Institute of Scientific Research for Labor and Social Protection \\ Povernei 6, Bucharest, Romania \\ ${ }^{3}$ National University of Political Studies and Public Administration, \\ Expozitiei 30 A, Bucharest, Romania,
}

E-mails. ${ }^{1}$ cristina.lincaru@yahoo.de; ${ }^{2}$ pirciog@incsmps.ro $;{ }^{3}$ adriana.grigorescu@snspa.ro; ${ }^{4} \underline{\text { tudose@incsmps.ro }}$

Received 21 July 2018; accepted 10 October 2018; published 30 December 2018

\begin{abstract}
Disruptive innovations generated by digital technologies push the public services to digital transformation in order to become not only a problems solver for community, but a real social, economic and environmental development engine. With all significant progress, the use of e-Government services in Romania remains the lowest in the EU; high quality services are not available in a significant part of rural areas. The paper highlighted the spatial heterogeneities of the broadband infrastructure at level of NUTS - 5 expansion correlated to Low-Low (LL) high human capital clusters in public administration and marginalized rural areas. Using data from World Bank studies, provided in the ArcGis Cloud, from Romanian broadband investment prioritization and micro data provided by INS census, we developed a spatial cluster analysis by the means of ESDA method. In public administration the high human capital is clustered in a few innovative
\end{abstract}

\footnotetext{
* This work was supported by a grant from the Romanian Ministry of Research and Innovation, Program Nucleu - PN 18_42_0101/Contract 12N/16.03.2018. Această lucrare a fost realizată prin Programul-nucleu, derulat cu sprijinul MCI, proiect nr. PN 18_42_0101/Contract 12N/16.03.2018" The dynamics of the labor market in Romania. Adaptive resilience and flexibility / Dinamica pieței muncii în România. Reziliență adaptivă și flexibilitate, coordinator Dr.. Speranța Pîrciog.
}

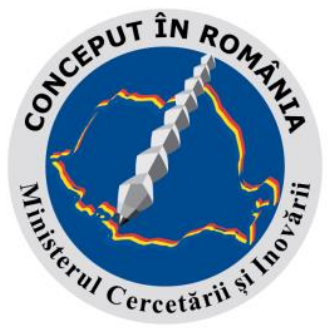


The International Journal
ENTREPRENEURSHIP AND SUSTAINABILITY ISSUES

ISSN 2345-0282 (online) http://jssidoi.org/jesi/

2018 Volume 6 Number 2 (December)

http://doi.org/10.9770/jesi.2018.6.2(18)

hubs which in the absence of a functional and interconnected national administration IT system makes difficult the public administration modernization, especially in the context of regional decentralization. At the county level is visible the pattern of center periphery, where the center is usually the county residence and the LL clusters are the frontier of the counties. Usually, at this frontier are located marginalized rural areas where are provided poor public services. As a recommendation, the future e-government development must be spatial harmonized with the high human capital in order to assure a valuable public service, everywhere, whether it is the smallest village or a big city, to reconnect the public to the state and the state to the public in an inclusive and intelligent manner.

Keywords: resilience; rural broadband; digital inclusion; digital public policies; human resources management

Reference to this paper should be made as follows: Lincaru, C., Pirciog, S., Grigorescu, A., Tudose, G. 2018. Low-Low (LL) High Human Capital Clusters In Public Administration Employment - Predictor for Digital Infrastructure Public Investment Priority - Romania Case Study, Entrepreneurship and Sustainabiliry Issues 6(2): 729-753. http://doi.org/10.9770/jesi.2018.6.2(18)

JEL Classifications: C54, M54, O47

Additional disciplines: administrative sciences; informatics

\section{Introduction}

Disruptive innovations generated by digital technologies push the public services in a new era. Digital public services becomes an innovation services based on technological progress and innovation for implementing real solutions to complex social, economic and environmental problems.

Minges (2015) points that broadband penetration has a complex impact on economic growth, playing the role of technology factor, influencing also the employment and productivity "as well as other dimensions of broadband (e.g., business penetration, speed etc.)". Kelly and Rossotto (2012) founds that "the impact of broadband on employment finding gains of between 2.5 and 4.0 additional jobs for each broadband job".

Philip et al. (2017) observed in the case of Great Britain telecommunications that even if the urban -rural digital divide is widely acknowledged the detailed accounts of the spatial patterns of digital communications infrastructure are rarely reported". The authors concludes that the urban-rural "digital divide is largely due to inadequate infrastructure" fact that request "to ensure that any public sector market interventions in broadband infrastructure developments are as effective as possible in addressing territorial digital divides".

- Typologies of connectivity solutions for spatial heterogeneities balance - digital innovation engines for changes

Urban-rural divide is a universal "law" generating diversified solutions "to bring connectivity to the 'final few' and to improve connectivity for the underserved. These, we suggest, will include some or all of the following: non fixed connection via satellite or wireless, particularly for the especially 'hard-to-reach' or 'final few' users; community-led initiatives which should be considered more systematically in public policy, especially in terms of financial and technical models most suited to local geographies and the socio-technical capacities of individual communities; and re-scoping potential models for collaboration between commercial service providers and the public sector (through public finance and/or provision of in-kind expertise) (Philip et al., 2017).

"There are significant issues with the inclusion of mobile broadband. First, the ability to use mobile broadband is dependent on the device and coverage. A mobile broadband subscription using a dongle and laptop would likely have different economic implications than using mobile broadband with a handset or smartphone. Second, there are problems with identifying active users versus those with the theoretical ability to use mobile broadband.13 Third, it is not clear whether broadband should be looked at overall—combining fixed and mobile 
The International Journal

ENTREPRENEURSHIP AND SUSTAINABILITY ISSUES

ISSN 2345-0282 (online) http://jssidoi.org/jesi/

2018 Volume 6 Number 2 (December)

http://doi.org/10.9770/jesi.2018.6.2(18)

subscriptions - or each mode should be examined separately. Existing studies always treat mobile and fixed broadband as separate variables" (Minges, 2015).

On the background of increases of spatial unbalances the emergence of an industrial revolution could bring personalized solutions for different location, increasing the access to prosperity in an inclusive manner. Digital innovation could offer complementary "bridges” to work, information and social relations for all members of the society regardless the age, sex, level of education, disabilities, location, etc. On this background the public services assumes the role of source of development, based on inclusiveness, resilience and information (SDG 9) (2017 HLFP Thematic Review of SDG-9: Build resilient infrastructure, promote inclusive and sustainable industrialization and foster innovation).

- Digital innovations in public services

Public services digitalization is the back bone of the socio-economic system, especially thorough investment in digital infrastructure, desirable to cover the full territory. In literature, the broadband connection is a measure of connectivity:

Brown (2015) presents the case of UK's Digital Inclusion Strategy, strategy that aims to remove hurdles from eAdministration. This initiative is implemented in an innovative way. The main innovations points the transitions from universal solutions to unique ones based on the local data, from a finalized version towards beta versions developed in the open, focused on easy use and universal accessibility (including person with disability or without digital skills). Also, it is a new focus, from website to services tailored to solve the beneficiary's problems.

Roberts et.al. (2017) critically examine the digital-rural policy in the community resilience framework bringing together the rural development and digital policy-related literature. Rural areas are community resilience, digital divides, digital inclusion, and rural information and communication technologies (ICTs). Whilst community broadband initiatives have been linked to resilience (Plunkett-Carnegie, 2012; Heesen et al., 2013) digital inclusion and engagement with new digital technologies more broadly, have not.

- Connectivity solutions and digital innovations in public services and their contribution to digitization of public services in rural area

Malecki (2003) points that "the concept of universal service is extended to encompass broadband connections, rural areas will need to demonstrate that they have adequate demand for digital communications", competing with urban areas. Broadband brings Internet and facilitate interaction among entreprenuers local and remote, connecting beyond communication in global economic chains the community. The emergence of modern type of bussines will keep and even attract youth in the rural community, optimist scenario to fill the barriers raised by the shortages of human capital.

The tremendous importance of overcoming the rural digital divide, solved with the state intervention, in emerging countries is illustrated by Shenglin et.al. (2017) with China's "Villages Connected" Programme. This Programme has a result "all villages now have some form or another of broadband internet access such as fixed, mobile or satellite". 


\section{The International Journal}

ENTREPRENEURSHIP AND SUSTAINABILITY ISSUES

ISSN 2345-0282 (online) http://jssidoi.org/jesi/

2018 Volume 6 Number 2 (December)

http://doi.org/10.9770/jesi.2018.6.2(18)

\section{Romania's development of the broadband infrastructure}

- Romania's general Performance in transition towards Digital Economy and Society

Countries such as Romania, which could leapfrog generations of networking technology and roll out fiber networks that support high speeds. (ITU 2017/I, p.112, see details in Annex1. Table B.)

The Digital Economy and Society Index (DESI, 2017), "Romania ranks 28th in DESI 2017. Romanians benefit from coverage of fast broadband connections in urban areas, which translates into the second highest share of subscriptions in the EU. The take-up of mobile broadband is also accelerating. However, the rate of digitization of the economy, including for public services, and the levels of digital skills are still low."

"Digital Public Services: Romania made significant progress in the availability of Open Data but the supply and use of e-Government services remain low." (DESI, 2017)

Europe's Digital Progress Report (EDPR, 2017, p.8) "In the Digital Public Services dimension, Romania's performance is below the EU average but with some progress. Romania has advanced mainly on the supply side by increasing the number of services which can be completed online and by automatically pre-filling forms for citizens."

Europe's Digital Progress Report - Telecom chapter (EDPR, 2017) "Romania is slowly progressing in terms of connectivity. The Romanian market is characterized by infrastructure-based competition, providing high-speed connections at affordable prices for the benefit of end-users in urban areas. However, high quality services are not available in a significant part of rural areas. In areas of market failure, European structural and investment funds remain the main drivers for the deployment of next generation network (NGN) infrastructure."

- National Policy framework

"The National Strategy for the Romanian Digital Agenda 2020 (approved by Government Decision nr. 245/7 April 2015) illustrates the government efforts in this regard. Special emphasis is placed on broadband development in rural and disadvantaged areas." (ITU 2017/II, p.152, see details in Annex1. Table C)

The 2020 Digital Agenda assumes among the 4 main actions domains the e-Government in the first domain (eGovernance, Interoperability, Cyber Security, Cloud Computing and Social Media - an area that aims to increase efficiency and reduce the costs of the public sector in Romania by modernizing the administration) and Broadband and services for digital infrastructure in the third domain (Broadband and digital infrastructure services - an area aimed at ensuring access to ICT and Internet equipment, increasing digital literacy).

In line with European targets, Romania aims at achieving 100 per cent households with fixed-broadband coverage by 2020,80 per cent households with over $30 \mathrm{Mbit} / \mathrm{s}$ broadband coverage and 45 per cent households with over 100 Mbit/s coverage." (ITU 2017/II, p.152, see details in Annex1. Table C).

- National methodology to classify the broadband infrastructure and conceptual terminology

The report of the World Bank (2015) has an objective the MSI support for operationalizing the National Plan regarding the infrastructure for new generation access and new generation networks (NGA \& NGN), approved in June 2015 through the HG 414. The scope of this investment plan is to develop the network distribution (backhaul) and to develop the transport network (backbone) already existent according to the new generation standards with ultra-fast NGA connections (figure 1).

The National Plan regarding the infrastructure for NGA\&NGN uses a terminology and typologies based on the European Commission framework described by the studies:

- Study on Broadband and Infrastructure Mapping (2014)

- $\quad$ Guide to High-Speed Broadband Investment, Version 1.1 (2014).

The methodology uses geospatial analysis of the socio-economic at village level conditions in relation with the communication market in view to prioritize the zones eligible for the stat interventions in NGA\&NGN. 
- "Backbone Network" means large-capacity high-capacity networks with a national coverage area with high reliability and low latency and high resilience;

- "Backhaul Network" /"the connection point Backbone" means the connection between Backbone and the local access points of the distribution network; Backhaul operators represent an intermediate link between the backbone and the local loop. Their networks extend the services provided by backbone operators to areas that are not covered, but are of interest to local loop operators.

- Local Broadband Access Point (PLABL) are technical spaces in buildings and / or separate buildings and related technical and utilities. Each administrative-territorial unit (LAU2) may have PLABL;

- the distribution network is the functional assembly of the transport elements and the associated terminal equipment, which is located in the perimeter of the white areas and is located between the backbone networks and the local access networks In the area of intervention of this project, the distribution network has different topologies in function the geographic location of users and the location conditions of the physical elements of the distribution network;

- "local loop (last mile)" means the physical circuit or its equivalent linking the client's premises to the distribution network's physical distribution network; (Ro-NET Project Presentation, p. 8).

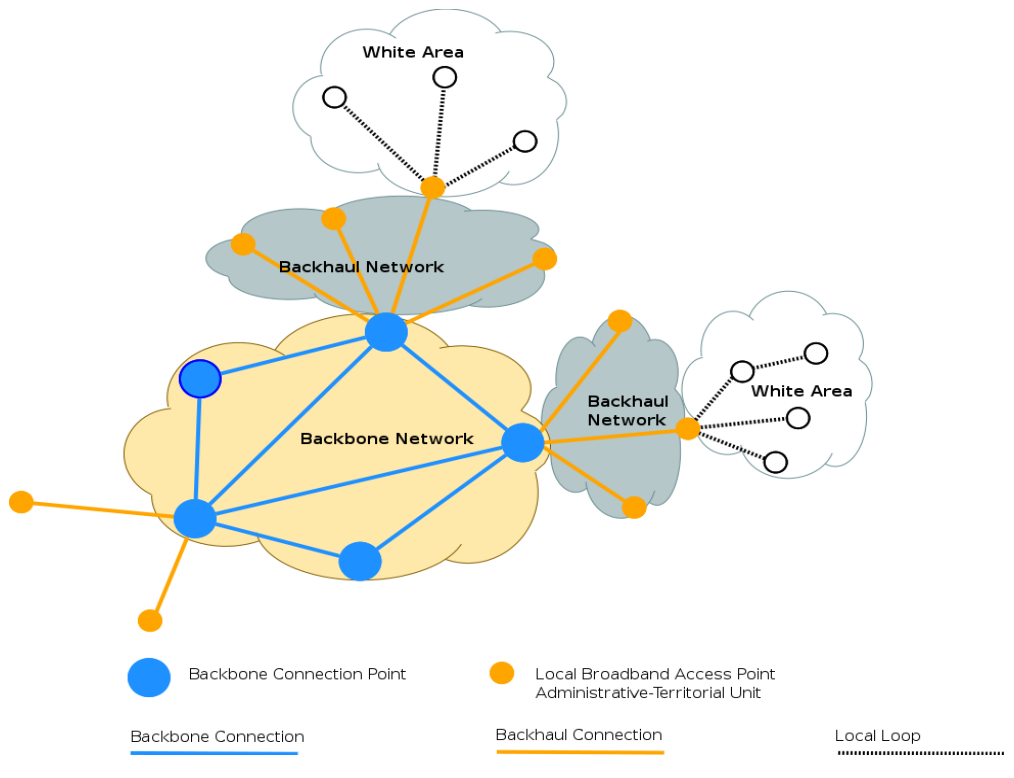

Fig. 1. The indicative broadband infrastructure used model in Ro-Net program

Source: Ro-NET Project Documentation, Despre RoNET, p.8

available at https://www.comunicatii.gov.ro/proiecte-in-implementare/proiectul-ro-net/

- Typology of broadband solutions adopted in Romania

In Romania, the "official" broadband infrastructure includes in its definition both typologies: mobile service and fixed services. Mobile-cellular and mobile-broadband penetration "are high and close to the European average and prices for both services are very affordable", with a good population coverage in a relatively good market diversity (there are 4 mobile operators on the market)". (ITU 2017/II, p.152) Fixed services, are the traditional solution but with high quality/complexity of the activities allowed "is relatively low compared to the European average and neighboring countries. Romania's national broadband plan identifies several reasons for this: the late market liberalization (2003) and launch of DSL services (2005), limited use of personal computers, high mobilebroadband take-up and low incomes, especially in rural areas." (ITU 2017/II, p.152) 
The International Journal

ENTREPRENEURSHIP AND SUSTAINABILITY ISSUES

ISSN 2345-0282 (online) http://jssidoi.org/jesi/

2018 Volume 6 Number 2 (December)

http://doi.org/10.9770/jesi.2018.6.2(18)

- Romania's level of development and perspective of the broadband infrastructure

The National Authority for Administration and Regulation in Communications (ANCOM) conducted an inventory of electronic communications networks in 2015. Were identified areas which at the end of December 2014 did not have a local loop and / or a backhaul network at a speed of 30 Mbps or over and were not involved in broadband projects funded by public funds (by MADR, Measure 322, or by MSI through the Ro-NET project). (World Bank 2015, p15) see table

According to ANCOM.v1 (2015) study, at 31 December 2014, in Romania, from the total of 13.755 villages /neighborhoods (SIRUTA units) from urban and rural zones, were registered the following broadband infrastructure state of development status:

- $\quad$ there were 6.457 villages (47\%) without local loop (last mile) networks for broadband communications at speeds of $30 \mathrm{Mbps}$ or above and not involved in broadband projects funded by public funds;

- 6.610 villages (48\%) without backhaul connections for broadband communications at $30 \mathrm{Mbps}$ or above and not involved in public broadband projects (World Bank, 2015, p.16)

World Bank (2015) study makes a synthesis of villages and LAU2 by priority of broadband investment by the main National Programs, from which we present only the rural selection (Table 1).

Table 1. Villages and LAU2 by priority of broadband investment by the main National Programs

\begin{tabular}{|c|c|c|c|}
\hline & $\begin{array}{l}\text { Candidate for } \\
\text { support from MSI } \\
(\text { Ro-NET) }\end{array}$ & $\begin{array}{l}\text { Members in a } \\
\text { GAL or GALP } \\
\text { Measure } 322 \text { MDRAP }\end{array}$ & Total \\
\hline \multicolumn{4}{|c|}{ At Villages (SIRUTA units) level } \\
\hline Rural & 4546 & 7827 & 12373 \\
\hline $\begin{array}{l}\text { Support for fixed broadband deployment \& demand boosting in } \\
\text { white villages in white communities }\end{array}$ & 68 & 59 & 127 \\
\hline Support only for the broadband infrastructure development & 175 & 436 & 611 \\
\hline $\begin{array}{l}\text { Support for broadband infrastructure development \& demand } \\
\text { stimulation }\end{array}$ & 309 & 598 & 907 \\
\hline Demand stimulation (only) & 1113 & 1824 & 2937 \\
\hline No state intervention & 2881 & 4910 & 7791 \\
\hline \multicolumn{4}{|c|}{ At the level of local administrative unit (LAU2/SIRSUP) } \\
\hline Rural & 995 & 1866 & 2861 \\
\hline $\begin{array}{l}\text { Support for fixed broadband deployment \& demand boosting in } \\
\text { white villages in white communities }\end{array}$ & 9 & 10 & 19 \\
\hline Support only for the broadband infrastructure development & 35 & 70 & 105 \\
\hline $\begin{array}{l}\text { Support for broadband infrastructure development \& demand } \\
\text { stimulation }\end{array}$ & 119 & 259 & 378 \\
\hline Demand stimulation (only) & 376 & 680 & 1056 \\
\hline No state intervention & 456 & 847 & 1303 \\
\hline
\end{tabular}

Source: selection from World Bank (2015, p.73) World Bank calculations 2015. Local Action groups (GALs) and Grupuri de Acţiune

Locală pentru Pescuit (GALPs) at the end of 2014, MADR - Ministry of Regional Development and Public Administration. Note: http://madr.ro/docs/dezvoltare-rurala/rndr/buletine-tematice/PT30.pdf

The technological characteristics follows the European Commission terminology as well as the concepts used by World Bank and MDRAP, with reference to the following definitions: 


\section{The International Journal}

ENTREPRENEURSHIP AND SUSTAINABILITY ISSUES

ISSN 2345-0282 (online) http://jssidoi.org/jesi/

2018 Volume 6 Number 2 (December)

http://doi.org/10.9770/jesi.2018.6.2(18)

- 'White zones NGN' refers to SIRUTA villages in rural and urban areas of Romania that do not have either local loop or backhaul broadband connections with a download speed of $30 \mathrm{Mbps}$ or above and are not involved in broadband projects funded by public funds in progress (either MADR or MSI). NGN white areas refers to the 2020 target of $80 \%$ coverage of broadband households at a speed of $30 \mathrm{Mbps}$ or above set by the National NGN Infrastructure Development Plan;

- „NGN white areas and 'white' areas (without networks and without operators) with basic broadband infrastructure. As defined by the European Commission, typical "white" areas refer to areas where broadband infrastructure does not exist and is unlikely to be implemented in the near future. By contrast, in some 'NGN' white areas, there is likely to be some infrastructure, but of a quality inferior to what is needed to achieve the Digital Agenda for Europe 2020 development goals." (World Bank, 2015)

- Project RO-NET is a major project (over 85.5 million Euro) initiated by the Communication Ministry since 2016 and is funded as Sectorial Operational Program "Increasing Economic Competitiveness" "Investing for Your Future!" "RO - NET Building a National Broadband Infrastructure in Disadvantaged Areas by Using Structural Funds" - a project co-financed by the European Regional Development Fund.

Vasilache (2017) cites the MIC Communicate from 6th October 2017 as response to HotNews.ro that the level of RO-NET implementation is:

- $\quad$ in October 2017 there were finalized high speed broadband implementation in 361 localities from the total of 783 marginalized localities targeted. MCSI has completed the reception in the territory, according to the provisions of HG 273/1994 (modified by HG 343/2017) and HG 51/1996 for a number of 150 localities.

- There are no financial corrections applied to the RO-NET project. In relation to the commitments assumed by the EC, the project runs according to the timetable approved by the project phase, the implementation of this project being eligible for the financial year 2014-2020.

- So far 62,639 thousand lei have been paid from the European Regional Development Fund (ERDF) and 30,180 thousand lei from the state budget.

- The expected completion deadline for the RO-NET project is the end of August 2018.“

These recent assessments of the high speed broadband penetration into territory do not take in consideration the penetration of digital competences and the Internet increasing using.

As we mention before, we focus on the high human capital employee into the - Act. 84 Public administration and defense; compulsory social security, containing on division, as a proxy for the public administration human resource involved in e governing digital services providing.

\section{E-Government services and public administration consolidation in Romania}

Another important target in Digital Agenda 2020 is that in 2020 at least $35 \%$ from all State Members citizens should use the e-Government systems. On this background the use of e-Government services remains the lowest in the EU. The official data of Eurostat emphasize the precarity of e-government in Romania in the areas where individuals are living in sparsely populated area (less than 100 inhabitants $/ \mathrm{Km}^{2}$ ). Example given, related to the user satisfaction about e-government websites, in 2013, only $1 \%$ of individuals getting satisfaction on the ease of using services on websites, compared to $27 \%$ of individuals in EU average.

Europe's Digital Progress Report (EDPR, 2017, p.8 "A series of measures taken by the Romanian Government targeted the reinforcement of governance and coordination of the implementation of e-government solutions. The position of coordinator of information technology, coordinated by a Secretary of State, was established. In addition an innovative initiative (GOVITHUB programme http://ithub.gov.ro/ ) managed to attract a high number of ICT experts to improve the quality of the public administration and open an entire 
The International Journal
ENTREPRENEURSHIP AND SUSTAINABILITY ISSUES

ISSN 2345-0282 (online) http://jssidoi.org/jesi/

2018 Volume 6 Number 2 (December)

http://doi.org/10.9770/jesi.2018.6.2(18)

innovation, digital and start-up ecosystem. The national administration IT system is fragmented, adding to the administrative burden for citizens and businesses. In the current competitive environment, Romanian public administrations have difficulties in attracting and retaining ICT specialists but programs like GovITHub have shown that public sector innovation is possible and ICT specialists can be found."

Strategy for Strengthening Public Administration 2014-2020 states as:

General Objective III: De-bureaucratization and Simplification for Citizens, Business and Administration

Specific objective III.1: Reducing bureaucracy for citizens Analyzing needs and objectives in terms of simplifying and rationalizing administrative procedures for citizens

This strategic approach requires, as a first step, to identify and analyze the real needs of public, simplifying and rationalizing the administrative procedures applicable to citizens, including a series of concrete measures relating to:

- inventory of areas of activity with major impact on citizens, with an emphasis on the main "life events". In order to highlight the main "life events", ministries and other competent central authorities will analyze, based on a methodology agreed by the National Committee for Coordination of Strategy Implementation and in line with the provisions of the National Digital Agenda for Romania, at least the following areas: persons and civil status documents, vehicle registration, labor and social benefits, health, education, payment of taxes and dues, housing and their collateral aspects etc., p.54.

The Revenue Administration Modernization Project RAMP (P130202) (91 million dollars based on a loan) has a slower than expected implementation, executed only $23.5 \%$ only for consultancy from 2013 until 2018, with a dead line in 31 March 2021. World Bank (2018), states that RAMP has managed to improve ANAF's business processes and provide training to over 500 managers but failed to centralize its tax payer information and introduce a sophisticated risk analysis system to support anti-fraud efforts. Finally, regardless the RAMP project evolution, ANAF needs to "upgrade its mission critical IT systems including urgently addressing IT maintenance, licensing, hardware needs, data security and staffing issues". (http://projects.worldbank.org/P130202/romania-tax-modernization-project?lang=en )

In 30 October 2017, through the Government Emergency Ordinance 77/2017, was established the National Centre for Financial Information NCFI (a structure without legal personality organized at the level of general management by reorganizing the General Directorate of Information Technology and taking over the activity in the field of information and communication technology, as well as the number of posts and personnel related to this activity from the central office of the National Agency for Fiscal Administration, from the General Tax Administration, from the National Agency for Public Procurement and from the National Commission for Prognosis.). NCFI's mission is to implement a Unique Management System for Information and Communication Technology Issues at the Public Finance System Managed by the Ministry of Public Finance and its subordinate units. The former Finance Minister, Ionut Misa (2017) had a press declaration mentioning that the Unique fiscal system has to join together, in a unique vision the whole information from 322 different data bases (from different programs).

\section{- Human capital from Public administration}

Employees are the main asset of public organizations. As a whole, the weight of the human capital employed in public administration, in 2016, in Romania represented $14.1 \%$ of total persons with tertiary education (ISCED) from 25 to 64 years compared to $9,5 \%$ of total employment in EU average. On the other side, in same year, Romania recorded only $5.1 \%$ from total employment in knowledge-intensive services compared to $7 \%$ from total employment in knowledge-intensive services in EU average. Regarding the level of development of e- 
government, we observe that Romania needs more scientists and engineers in public administration, they representing $3.1 \%$ from total employment in this area; the gap is 1.6 percentage points to reach the level of E.U.28 scientists and engineers in public administration (from 25 to 65 years) in 2016. Another relevant indicator for the lack of infrastructure development of digital public services across the country is the number of technicians and associate professionals. In the Figure 2 we can observe the occupations distribution profile compared to E.U.28, the underrepresentation of technicians detrimental to professionals and other occupations.

A digital infrastructure for e-government needs engineers, scientists and technicians to be developed, maintained or to create and to sustain digital innovative public services. The statistical data highlight a distribution of human resources related to the level of actual public services development: insufficient institutional development which is not able to offer to all citizens a qualitative public service.

Employees from public services in the perspective of innovative digital services need to think beyond legislation, to be open to experimentations in order to achieve desired policy outcomes. (European Commission, 2017) To produce public value the management should know how to use better its employees, their capabilities, their professional and soft skills in an organizational environment appropriate to innovative digital public services, ready to ,anticipate societal challenges and address them proactively in order to reduce shocks for citizens and business." (European Commission, 2017)

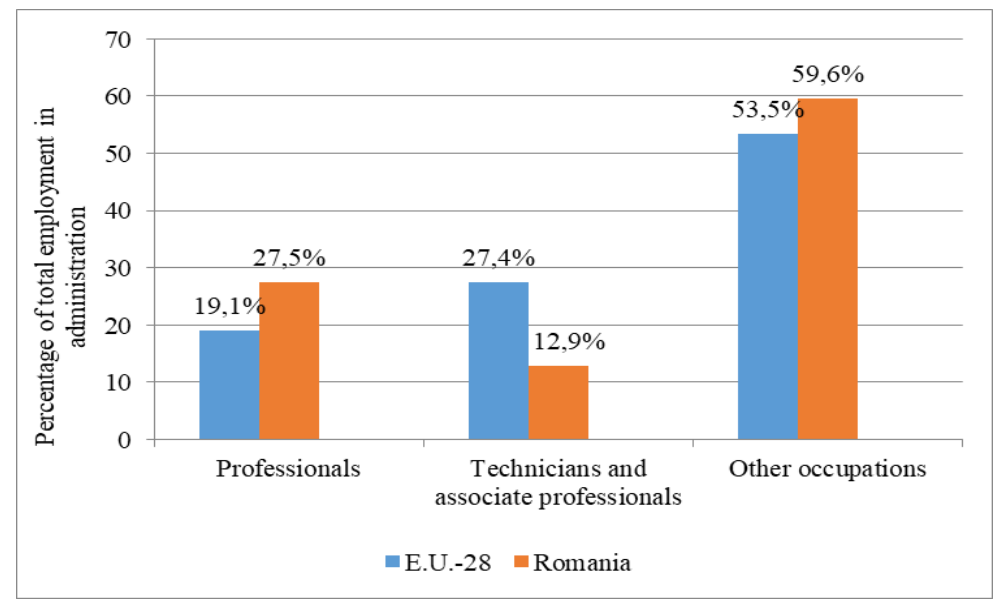

Fig.2. Employees distribution in Romanian public administration

Source: Eurostat data ([htec_emp_nisco2]), authors representation

The importance of specialized human capital is reflected by the continuous monitoring the indicator: Share of the public-sector staff with basic digital competences from all public staff in the central public administration (M\&E Manual, 2017), action in the Ministry of Regional Development and Public Administration MDARAP responsibility according to the 2020 Digital Agenda.

In this paper we analyze the spatial challenges related to modernization of public services, using the spatial human capital development as a proxy for institutional development and the broadband investment prioritization expansion. Gatman (2011) points that e-Government success in Romania is conditioned by equally important and complementary three dimensions: financial (as a prerequisite for technology - our comment), human resources and policy. We use data for the High human capital, tertiary salaried persons with activities in "Public administration and defense; compulsory social security" coded as division 84 /ISIC Rev.4 by LAU2 level (in short 


\section{The International Journal}

ENTREPRENEURSHIP AND SUSTAINABILITY ISSUES

ISSN 2345-0282 (online) http://jssidoi.org/jesi/

2018 Volume 6 Number 2 (December)

http://doi.org/10.9770/jesi.2018.6.2(18)

Act 84). This is the highest granularity in terms of statistics both in economic activity and space description, allow us to apply lattice data model and explore it with ESDA spatial analysis tools.

\section{Data, indicators and feature layers}

Our main data is the indicator High human capital - total and tertiary employees by sex, age and level of education from Act 84, at NUTS 5 level /LAU 2 level using Population Census Data 2011 (RPL 2011) micro data provided by INS. Following the spatial analysis we create a Feature Layer 1 which describes the clusters $\mathrm{HH}$ and LL of this population.

We consider useful to comment the high complexity and huge diversity of the activities included under the statistic umbrella of Act 84. Annex 1 Table A illustrate the large spectrum of activities, including: Administration of the State and the economic and social policy of the community, Provision of services to the community as a whole and compulsory social security activities. In theoretical terms, the public services should implement the economic and social policy of tech community through general activities (focused on budget administration, tax collection, planning and statistical services), activities to increase personal well-being (health, education, culture, sport, recreation, environment, housing, social services) and Regulation of and contribution to more efficient operation of businesses (public administration and regulation, including subsidy allocation, administration of $\mathrm{R} \& \mathrm{D}$ policies and associated funds to improve economic performance, administration of general labor affairs, implementation of regional development policy measures etc.). These economic activities are structured in mutually exclusive categories; each of these categories reflects continuous needs for each local community, with more or less services, according to its level of development. Urban areas presents lager services pallet while rural areas presents diminished access to few services, while the needs are increasing.

Among the important advantages of the GIS analysis are the multilevel analyses overlapping different standardized maps. While the best image of Romania's broadband infrastructure is public in Arc GIS Cloud other 5 Feature layers, owned by World Bank, at the highest granularity - village we use the following:

Feature Layer 2: Romania Broadband Investment Prioritization regarding broadband and Next Generation Networks (NGN) investment interventions. (created in January 11, 2017) with Credit to National Agency of Cadaster and Land Registration, National Authority for Management and Regulation in Communications, Ministry of Information Technology and Communications. This Feature Layer "represents the degree of priority investments in broadband depending on the areas correlation with the development needs and economic potential of the villages.

Feature Layer 3: Romania Marginalized Rural Areas regarding broadband and Next Generation Networks (NGN) investment interventions. (created in January $11^{\text {th }}, 2017$ ) with Credit to National Agency of Cadaster and Land Registration, National Institute of Statistics, Census of Population and Dwellings 2011. This Feature Layer represents "the proportion of population living in marginalized rural areas disadvantaged in human capital, formal employment, and housing conditions."

Feature Layer 4: Marginalized areas are compact territories within localities (neighborhoods, villages, hamlets, etc.) where extremely poor people, such as ghettos or slums. Thus, the proportion of the population living in marginalized areas offers an extremely unacceptable multidimensional property that tends to become chronic and transmitted from one generation to the next. At national level, $6.2 \%$ of the rural population, $5.3 \%$ of households and $5.2 \%$ of households are located in marginalized rural areas. The data used are based on the 2011 Population and Housing Census in two previous World Bank studies (2014 and 2015). 


\section{The International Journal}

ENTREPRENEURSHIP AND SUSTAINABILITY ISSUES

ISSN 2345-0282 (online) http://jssidoi.org/jesi/

2018 Volume 6 Number 2 (December)

http://doi.org/10.9770/jesi.2018.6.2(18)

Feature Layer 5: Marginal rural areas, according to World Bank (2015b), are scenes with severe deficiencies that bring together people who have attained lower secondary education, earn their livelihood in the informal sector (especially agriculture) and live in precarious conditions even for the rural context that generally has low access to infrastructure and basic utilities (living in overcrowded housing and / or without access to running water or electricity). These marginalized areas are recognized as 'problematic', especially due to the combination of a low income household's concentration, low levels of education and relevant skills in the labor market, a preponderance of single mothers, high numbers of children and a high rate of minor offenses. Even more than other rural communities, marginalized areas have poor physical accessibility, unpaved roads, inadequate housing, are exposed to environmental risks (floods, landslides, etc.) and their public services are absent or of poor quality.

Feature Layer 6: Marginalized areas (or census sectors) were defined by World Bank (2015c) as those that were disadvantaged in all three respects (i) human capital; (ii) formal employment of the workforce; and (iii) housing conditions. The analysis was carried out at the level of the census sectors.

\section{Research Methodology and Model}

Krugman, Venables and Fujita (1999) in New Economy of Geography - the production is heterogeneously distributed in space, reflecting the tendency of agglomeration in highly populated locations. The success of local economies is generated by the presence of the new in both tradable and non-marketable sectors. The sectors adopting and using the new and innovation are sectors that generate new jobs in the region / location indirectly and in other sectors. In other words, high human capital agglomerations generate spillover effects called positive externalities. Moretti \& Thulin (2013) found that this "multiplier effect is particularly large for jobs with high levels of human capital and for high technology industries". In other words, "the impact on a local labor market of attracting a high-technology employer to a city is three times larger than the impact of attracting a low-technology employer of similar size", (Moretti, Thulin, 2013).

Pelinescu highlighted the human capital as essential factor in „ensuring economic growth expressed as gross domestic product per capita" (Pelinescu, 2015) "of competitiveness in knowledge society" (Pelinescu, 2016) which strongly influences the innovation level of knowledge society as well as their efficiency". (Pelinescu et.al, 2014) Stroe \& Cojanu (2017) warns for Romania the phenomenon of increasing the in work poverty importance, fact that put in difficulty the functionality of innovation as the engine of the modern economy stress in the absence of an adequate wage policy, able to "restoring the wage-productivity correlations destroyed during the period of transition" (Pelinescu et. al., 2011).

Digital transformation for public administration reason its transtition from the base economy public administration supply into location services consumed local. In this perspective, this sector should act as non-base sector, but providing best environment for base sectors, sectors that produce for external location consumption, in global competitive parameters. This theoretical model, is adaptated, kipping in mind the specific of the Romanian country in regard the profile, structure and spatial distribution of the five feature layers, equivalent of a multivariate visual analyse tool. These layers intersect in spatial profile the: public administration's tertiary employees, the Digital Infrastructure Public Investment Priority (feature layers 2-5) based on poverty profile at the village scale level. An important share of the public services represents activities of a governmental nature, normally carried out by the public administration, coded in NACE Rev.2 statistics as Section: O - Public administration and defense; compulsory social security, containing on division Act. 84 with the same name. This section is divided into the following Groups: 841 - Administration of the State and the economic and social policy of the community; 842 - Provision of services to the community as a whole and 843 - Compulsory social security activities. 
The International Journal
ENTREPRENEURSHIP AND SUSTAINABILITY ISSUES

ISSN 2345-0282 (online) http://jssidoi.org/jesi/ 2018 Volume 6 Number 2 (December)

http://doi.org/10.9770/jesi.2018.6.2(18)

In Annex 1 are presented results of the model we applied: ESDA - LISA analysis for spatial distribution of the high human capital using the indicator employees with tertiary education in Act 84. We identified the spatial clusters/ agglomerations identification HH and LL type focus on at NUTS 5 level /LAU 2 level using RPL 2011 micro data provided by INS.

Maps overlay in view to identify spatial patterns in Arc Gis Desktop.

\section{Research results}

The spatial analysis (Anselin 2003, 2005, 2016) reveals for Romania a pronounced agglomeration tendency of high skilled employees from Act.26 at NUTS 5/LAU2 level, synthetically presented in Figure 3. Under the Null Hypothesis NH: complete spatial randomness (CSR), in condition Queen contiguity spatial weight rule for weighting of 1 st order by SIRUTA for a number of permutation $=999, p$ value 0.05 with a $90 \%$ confidence level we reject $\mathrm{NH}$ and make the decision of clustering tendency, there is no spatial randomness. Applying Univariate Local Moran's, calculated in GeoDa 1.10.0.8 we obtain the following results: the Moran's I is 0.0094, higher than theoretical value of -0.0003 , with a pseudo $\mathrm{p}$ value 0.05 , sd of 0.0047 , z-value $2.0996>1.65$.

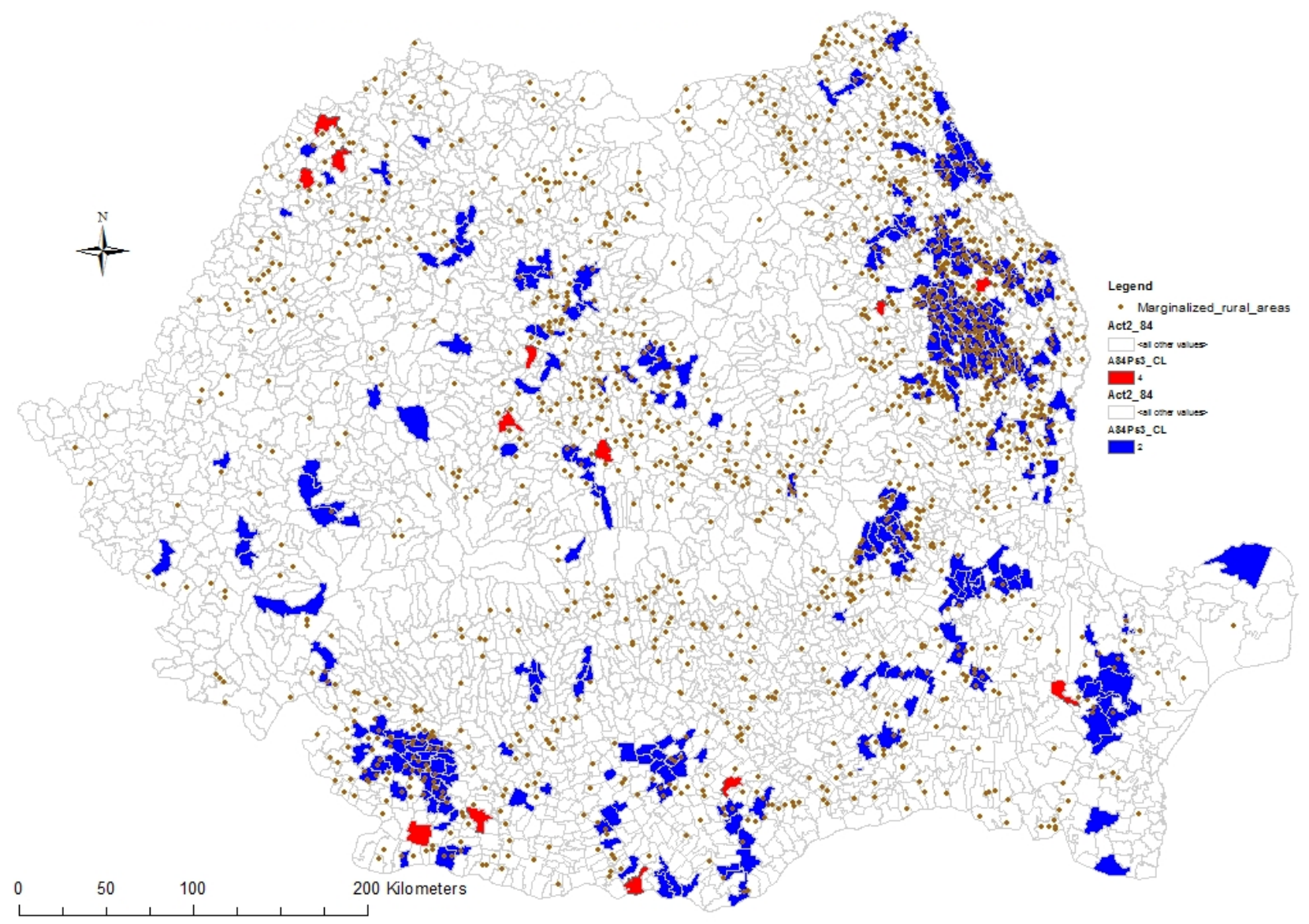

Fig. 3. Map1. The HH and LL clusters for the tertiary employees in Act 84 in 2011 (RPL data INS) and Marginalized rural areas (World Bank 2017 Feature Layer, Territorial Observatory, MDRAP) at Lau2 level and villages

Source: Map realized by authors in Arc GIS, using data from Arc Cloud, NUTS5/LAU2 shape file ESRI Romania 
The International Journal

ENTREPRENEURSHIP AND SUSTAINABILITY ISSUES

ISSN 2345-0282 (online) http://jssidoi.org/jesi/ 2018 Volume 6 Number 2 (December)

http://doi.org/10.9770/jesi.2018.6.2(18)

The result of spatial analysis for all 3189 LAU2, indicates a spatial clusters tendency for both employees and high human capital (Figure 3 Map 1), registering positive spatial autocorrelation with agglomeration tendency in two types of clusters: Innovative hubs (HH locations with high level of number of employees having in neighborhood locations with high level of employees, counting 13 locations) and Black holes (LL locations with low level of number of employees having in neighborhood locations with low level of employees, counting 294 locations).

Maps that illustrates the spatial correlation between LL high human capital cluster and marginalized villages and broadband expansion priorities, in the MCI framework.

Table 2 (presents detailed statistics for Figure 3) emphasize as the main gap between rural and urban areas the agglomeration of low skilled employed person in public administration in rural area as well as high concentration of youth and aged employees, compared to urban areas. The share of rural population in Romania is around $44.8 \%$ but the coverage in public administration employees is only $25 \%$.

Table 2: General statistics regarding employment in public administration in rural, urban and average LAU2 units in 2011 by sex, level of education and group age

\begin{tabular}{|c|c|c|c|c|c|c|c|c|c|c|c|c|c|c|c|c|c|c|c|c|c|}
\hline \multirow[b]{2}{*}{ sex } & \multirow[b]{2}{*}{$\begin{array}{c}\text { level of } \\
\text { education }\end{array}$} & \multirow[b]{2}{*}{$\begin{array}{c}\text { age group } \\
\text { [years] }\end{array}$} & \multicolumn{6}{|c|}{ rural } & \multicolumn{6}{|c|}{ urban } & \multicolumn{6}{|c|}{$\begin{array}{l}\text { number of persons } \\
\text { total }\end{array}$} & \multirow[b]{2}{*}{$\begin{array}{c}\text { Share } \\
\text { Sum rural/ } \\
\text { Sum total }\end{array}$} \\
\hline & & & Mean & \begin{tabular}{|c|} 
Std. \\
Error \\
of \\
Mean
\end{tabular} & Sum & Max & $\begin{array}{c}\text { Std. } \\
\text { Deviation }\end{array}$ & Variance & Mean & $\begin{array}{c}\text { Std. } \\
\text { Error of } \\
\text { Mean }\end{array}$ & Sum & $\operatorname{Max}$ & $\begin{array}{c}\text { Std. } \\
\text { Deviation }\end{array}$ & Variance & Mean & $\begin{array}{c}\text { Std. } \\
\text { Error of } \\
\text { Mean }\end{array}$ & Sum & $\operatorname{Max}$ & \begin{tabular}{|c|} 
Std. \\
Deviation
\end{tabular} & Variance & \\
\hline total & total & total & 38,04 & ,669 & 109368 & 532 & 35,893 & 1288,334 & 1064,28 & \begin{tabular}{|l|}
254,190 \\
\end{tabular} & \begin{tabular}{|l|}
334183 \\
\end{tabular} & 76037 & 4504,250 & 20288263,824 & \begin{tabular}{|l|}
139,09 \\
\end{tabular} & 25,579 & 443551 & 76037 & 1444,505 & \begin{tabular}{|l|}
2086593,630 \\
\end{tabular} & 25 \\
\hline males & total & total & 22,93 & ,404 & 65929 & 309 & 21,680 & 470,022 & 593,13 & 129,076 & 186243 & 38185 & 2287,237 & \begin{tabular}{|l}
5231454,657 \\
\end{tabular} & 79,08 & 13,048 & 252172 & 38185 & 736,832 & 542921,517 & 26 \\
\hline females & total & total & 15,11 & ,291 & 43439 & 237 & 15,621 & 244,002 & 471,15 & \begin{tabular}{|l|}
125,393 \\
\end{tabular} & 147940 & 37852 & 2221,978 & 4937185,141 & 60,01 & 12,564 & 191379 & 37852 & 709,523 & 503423,109 & 23 \\
\hline total & low & total & 4,33 & ,168 & 12439 & 306 & 8,995 & 80,918 & 34,78 & 8,193 & 10920 & 2524 & 145,173 & 21075,171 & 7,32 & ,835 & 23359 & 2524 & 47,164 & 2224,457 & 53 \\
\hline total & medium & total & 18,38 & ,286 & 52837 & 163 & 15,313 & 234,500 & 346,88 & 73,510 & \begin{tabular}{|l|}
108919 \\
\end{tabular} & 21991 & \begin{tabular}{|l|}
1302,602 \\
\end{tabular} & 1696772,735 & 50,72 & 7,437 & 161756 & 21991 & 419,981 & 176383,771 & 33 \\
\hline total & high & total & 15,34 & 368 & 44092 & 392 & 19,750 & 390,051 & 682,62 & \begin{tabular}{|l|}
172,808 \\
\end{tabular} & \begin{tabular}{|l|}
214344 \\
\end{tabular} & 51522 & 3062,158 & 9376814,497 & 81,04 & 17,355 & 258436 & 51522 & 980,057 & \begin{tabular}{|c|}
960512,218 \\
\end{tabular} & 17 \\
\hline total & total & $15-24$ & 1,80 & 045 & 5168 & 32 & 2,406 & 5,789 & 35,09 & 8,011 & 11019 & 2404 & 141,958 & \begin{tabular}{l|}
20151,982 \\
\end{tabular} & 5,08 & 808 & 16187 & 2404 & 45,631 & 2082,188 & 32 \\
\hline total & total & $25-54$ & 31,93 &, 592 & 91800 & 491 & 31,718 & 1006,036 & 931,40 & 221,391 & 292459 & 66109 & 3923,053 & 15390343,582 & 120,50 & 22,285 & 384259 & 66109 & \begin{tabular}{|l|l|}
1258,484 \\
\end{tabular} & 1583781,215 & 24 \\
\hline total & total & $55+$ & 4,31 & 070 & 12400 & 59 & 3,735 & 13,953 & 97,79 & 24,885 & 30705 & 7524 & 440,955 & 194441,529 & 13,52 & 2,497 & 43105 & 7524 & 140,992 & 19878,821 & 29 \\
\hline \multirow{9}{*}{$\frac{\infty}{\frac{\infty}{\infty}}$} & low & $15-24$ &, 15 &, 016 & 426 & 23 & ,882 & ,778 & ,74 &, 130 & 232 & 35 & 2,295 & 5,267 & ,21 & ,020 & 658 & 35 & 1,118 & 1,249 & 65 \\
\hline & low & $25-54$ & 1,56 & ,086 & 4484 & 184 & 4,622 & 21,365 & 9,70 & 1,992 & 3046 & 613 & 35,306 & \begin{tabular}{|l|}
1246,504 \\
\end{tabular} & 2,36 & ,215 & 7530 & 613 & 12,146 & 147,528 & 60 \\
\hline & low & $55+$ &, 45 & 022 & 1302 & 33 & 1,168 & 1,365 & 3,14 & ,709 & 986 & 217 & 12,560 & $\begin{array}{l}157,763 \\
\end{array}$ & ,72 & , 074 & 2288 & 217 & 4,167 & 17,361 & 57 \\
\hline & medium & $15-24$ &, 71 & ,023 & 2034 & 24 & 1,242 & 1,543 & 12,24 & 2,152 & 3842 & 606 & 38,125 & 1453,510 & 1,84 & ,221 & 5876 & 606 & 12,486 & 155,899 & 35 \\
\hline & medium & $25-54$ & 10,50 & ,181 & 30189 & 108 & 9,684 & 93,775 & 193,24 & 35,973 & 60678 & 10526 & 637,437 & 406325,762 & 28,49 & 3,670 & 90867 & 10526 & 207,227 & 42943,180 & 33 \\
\hline & medium & $55+$ & 1,44 & 027 & 4153 & 14 & 1,454 & 2,115 & 19,98 & 4,631 & 6275 & 1407 & 82,061 & $\begin{array}{l}6733,933 \\
\end{array}$ & 3,27 & ,466 & 10428 & 1407 & 26,336 & 693,569 & 40 \\
\hline & high & $15-24$ & ,31 &, 012 & 890 & 6 & ,666 & ,444 & 9,30 & 2,410 & 2921 & 728 & 42,699 & 1823,183 & 1,20 & ,242 & 3811 & 728 & 13,660 & 186,583 & 23 \\
\hline & high & $25-54$ & 6,80 & ,181 & 19551 & 199 & 9,686 & 93,817 & 311,57 & 73,592 & 97833 & 21704 & 1304,059 & 1700568,648 & 36,81 & 7,414 & 117384 & 21704 & 418,683 & 175295,362 & 17 \\
\hline & high & $55+$ & 1,01 & ,024 & 2900 & 14 & 1,281 & 1,640 & 33,22 & 7,928 & 10430 & 2349 & 140,491 & $\begin{array}{l}19737,787 \\
\end{array}$ & 4,18 & ,798 & 13330 & 2349 & 45,072 & 2031,460 & 22 \\
\hline \multirow{9}{*}{ 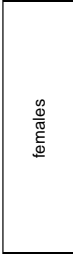 } & low & $15-24$ &, 09 &, 007 & 255 & 7 & ,388 & ,150 & ,72 & ,195 & 225 & 58 & 3,454 & 11,929 & ,15 & , 021 & 480 & 58 & 1,158 & 1,342 & 53 \\
\hline & low & $25-54$ & 1,68 &, 051 & 4833 & 53 & 2,733 & 7,471 & 16,12 & 4,186 & 5062 & 1289 & 74,168 & 5500,899 & 3,10 & ,421 & 9895 & 1289 & 23,777 & 565,332 & 49 \\
\hline & low & $55+$ & ,40 & ,016 & 1139 & 17 & 842 &, 710 & 4,36 & 1,043 & 1369 & 312 & 18,481 & 341,541 & ,79 &, 106 & 2508 & 312 & 5,964 & 35,568 & 45 \\
\hline & medium & $15-24$ & ,23 &, 010 & 652 & 4 &, 513 & ,263 & 4,23 & ,876 & 1327 & 260 & 15,531 & 241,217 & ,62 & ,089 & 1979 & 260 & 5,034 & 25,340 & 33 \\
\hline & medium & $25-54$ & 4,86 & ,093 & 13972 & 60 & 4,977 & 24,771 & 99,78 & 25,590 & 31330 & 7789 & 453,451 & 205618,033 & 14,21 & 2,567 & 45302 & 7789 & 144,948 & 21010,040 & 31 \\
\hline & medium & $55+$ & ,64 & 018 & 1837 & 9 & ,944 & ,890 & 17,41 & 4,635 & 5467 & 1403 & 82,130 & $\begin{array}{l}6745,310 \\
\end{array}$ & 2,29 & ,464 & 7304 & 1403 & 26,231 & 688,040 & 25 \\
\hline & high & $15-24$ & ,32 &, 012 & 911 & 8 & ,660 & ,435 & 7,87 & 2,354 & 2472 & 717 & 41,719 & $\begin{array}{ll}1740,463 \\
\end{array}$ & 1,06 & ,235 & 3383 & 717 & 13,279 & 176,341 & 27 \\
\hline & high & $25-54$ & 6,53 & ,168 & 18771 & 174 & 8,992 & 80,862 & 300,99 & 80,677 & 94510 & 24188 & 1429,592 & 2043734,422 & 35,52 & 8,084 & 113281 & 24188 & 456,538 & \begin{tabular}{|l|}
208427,264 \\
\end{tabular} & 17 \\
\hline & high & $55+$ & ,37 & 014 & 1069 & 9 & ,734 & ,539 & 19,68 & 6,041 & 6178 & 1836 & \begin{tabular}{ll|}
107,041 \\
\end{tabular} & \begin{tabular}{l|}
11457,709 \\
\end{tabular} & 2,27 & ,603 & 7247 & 1836 & $\begin{array}{ll}34,037 \\
\end{array}$ & 1158,499 & 15 \\
\hline & & & & & & & & & & & & & & & & & & & & $\%$ & \\
\hline \multicolumn{3}{|c|}{ share males } & 60,7 &, 2230 & & 100,0 & 11,9550 & 142,923 & 59,9 & .4369 & & 79,2 & 7,7421 & 59,940 & 60,6 & 2056 & & 100,0 & 11,6094 & 134,778 & \\
\hline \multicolumn{3}{|c|}{ share females } & 39,1 & ,2194 & & 76,2 & 11,7652 & 138,419 & 39,7 & ,4127 & & 59,5 & 7,3131 & 53,481 & 39,2 & ,2020 & & 76,2 & 11,4049 & 130,071 & \\
\hline & \multicolumn{2}{|c|}{ share low level education } & 11,4 & ,1817 & & 84,6 & 9,7440 & 94,945 & 6,4 & 2871 & & 45,1 & 5,0874 & 25,882 & 10,9 & , 1683 & & 84,6 & 9,5030 & 90,308 & \\
\hline & \multicolumn{2}{|c|}{ share medium level education } & 49,9 & ,2427 & & 100,0 & 13,0133 & 169,347 & 41,4 & ,4956 & & 68,4 & 8,7824 & 77,130 & 49,1 & ,2285 & & 100,0 & 12,9055 & 166,553 & \\
\hline & \multicolumn{2}{|c|}{ share high level education } & 38,6 & 2563 & & 100,0 & 13,7406 & 188,804 & 51,8 & 6080 & & 77,8 & 10,7734 & 116,065 & 39,9 & 2487 & & 100,0 & 14,0441 & 197,238 & \\
\hline & & share youth & 4,6 & ,0902 & & 46,2 & 4,8355 & 23,382 & 4,1 & 1394 & & 29,9 & 2,4693 & 6,098 & 4,5 & ,0825 & & 46,2 & 4,6585 & 21,702 & \\
\hline & & share adult & 82,3 & $\begin{array}{l}, 1816 \\
\end{array}$ & & 100,0 & 9,7372 & 94,813 & 86,0 & 3570 & & 97,3 & 6,3268 & 40,029 & 82,7 &, 1685 & & 100,0 & 9,5180 & 90,592 & \\
\hline & & share aged & 12,9 & ,1556 & & 60,0 & 8,3421 & 69,590 & 9,6 & , 1964 & & 27,0 & 3,4800 & 12,111 & 12,5 & ,1426 & & 60,0 & 8,0536 & 64,861 & \\
\hline
\end{tabular}

Source: data calculated by authors using Census Population 2011 micro data provided by INS 


\section{The International Journal}

ENTREPRENEURSHIP AND SUSTAINABILITY ISSUES

ISSN 2345-0282 (online) http://jssidoi.org/jesi/

2018 Volume 6 Number 2 (December)

http://doi.org/10.9770/jesi.2018.6.2(18)

Gasik (2016) founds that is a "greater complexity of managing public projects than of managing projects in other sectors", where "the most complicated public projects management areas are stakeholder management, procurement management, and communications management".

Seri \& Zanfei (2013) establishes that there are "complementarities between ICT, human capital and organizational change" are most important.

Our starting point analysis is based on the Seri \& Zanfei (2013) conclusion that "ICT alone does not significantly impact on PA (public administration) performance, while it does when combined with human capital and organizational change". On these postulates, based on the Figure 3 and Table 2 looks that Romania, is trapped in a vicious circle. This circle starts from the shortage of high human capital especially in locations with low economico\&social performance, locations where is a high demand for public interventions, put at risk the ICT as an essential step towards organizational change of PA.

\section{Romania Case study}

As a result of overlapping all the Feature layers we present the Figure 4. Map 2 with version A and B and with the Figure 5. Detail 1 Vaslui and surroundings and Figure 6. Detail 2 Mehedinţi and surroundings. In Figure 4. Map 2 A. is visible that LL locations with high human capital in public administration are disjoint with the area with market potential, location: Locations with No State intervention in Broadband investment.

In Map 2 B are presented the typologies of Broadband investments by action type, Marginalized rural areas and the LL locations with high human capital in public administration, as follows:

- The Action type "Support for fixed broadband deployment \& demand boosting in white villages in white communities". This is the case of small, declining, isolated, peripheral locations LAU2 with low market potential for sure not digital covered at the minimum $>=30 \mathrm{Mbps}$. The Model applied in isolated and marginalized areas cover Western counties mostly, especialy: Poiana Iancului, Buzeștii de Sus, Alba, Ploscos, Hunedoara, Mehedinți (Poroina Mare, Padina, Corlatel), Vrancea, Buzău, Neamț. Also these areas are LL areas with public administration employee's fact that indicates a low access to public administration services;

- The Action type "Support only for the broadband infrastructure development" This is the case of LAU2 without MADR or Ro-NET projects was identified in 1,111 SIRUTA units (of which only 4 are urban areas), but only 55\% (611) of which are poor or very poor rural areas that are eligible for support from the state. (World Bank, 2015) In these marginalized areas is possible the support / stimulation for the implementation of high-speed broadband $(30+\mathrm{Mbps})$ in at least one village in the commune in a sustainable manner. The spatial distribution is heterogeneously with many dense areas Iași/ Bacău/ Vaslui/ Galați, Botoșani, Vrancea\& Buzău, also with dispersed dense areas Satu Mare, Marmureș, Sălaj, Bistrița Năsăud, Hunedoara, Mehedinți, Teleorman, Giurgiu, Centre of Transylvania. This type of action reflects the Model applied especially in eastern marginalized areas, areas which are also with a high probability LL location types by the public administration employees. It is confirmed the low access to public administration services, regardless the high level of needs;

- The Action type "Support for broadband infrastructure development \& demand stimulation". This is the case of LAU2 locations that have the "need for public intervention to support the development of broadband infrastructure along with demand-side needs are found in 1,512 SIRUTA units (of which only 5 of urban areas). Of these villages, white villages belonging to white communes (127) have a maximum economic potential of medium, so they are all eligible for state support. Other 907 poor or very poor villages are also eligible for state support. In addition, all other 478 ineligible villages for support in 
broadband deployment can benefit from demand-boosting measures". (World Bank, 2015) There are agglomeration at the counties frontiers: Mehedinți \& Dolj, Alba\& Hunedoara, Mureș, Vrancea, Neamț. This action model is applied especially in Western marginalized areas, areas of LL type with low level of public administration employees. It is confirmed the low access to public administration services, regardless the high level of needs;

- The Action type "Demand stimulation (only) - Stimulating the demand for (broadband) Internet services and the use of the Internet". This is the case of locations where is increased only the service offer, "in particular by developing services such as e-commerce, e-health, e-education and e-government, in 4,102 villages (131 urban), of which about 40\% have medium economic potential to high" (World Bank, 2015). This action model is applied especially in western isolated and some marginalized areas but also in no marginalized areas, at counties frontiers: Bistrița/ Cluj, Nord-Vest Mureș, N-V Alba, Mehedinți, S Vâlcea, N Olt, V Argeș, N Teleorman, Buzău, Vrancea, Iași/ Bacău/ Vaslui/ Galați, Tulcea. In marginalized locations this action is coupled with other action types presented before in neighborhood locations, highly correlated with the presence of LL locations of public administration high capital employees. There are compact areas with this action only, location with good economic potential outside the LL areas!

- The Action type „No state intervention" is applied in "black areas the market is expected to be developed without state intervention. If MADR projects support implementation of both backhaul and local loop, the Ro-NET project only finances backhaul implementation with a contract through which a local loop will be developed by private investors in the near future". (World Bank, 2015) These areas that are not included in marginalized areas and are also outside the LL locations.

As a conclusion, we could affirm that Low-Low (LL) High Human Capital Clusters in Public Administration Employment is a good Predictor for Digital Infrastructure Public Investment Priority.

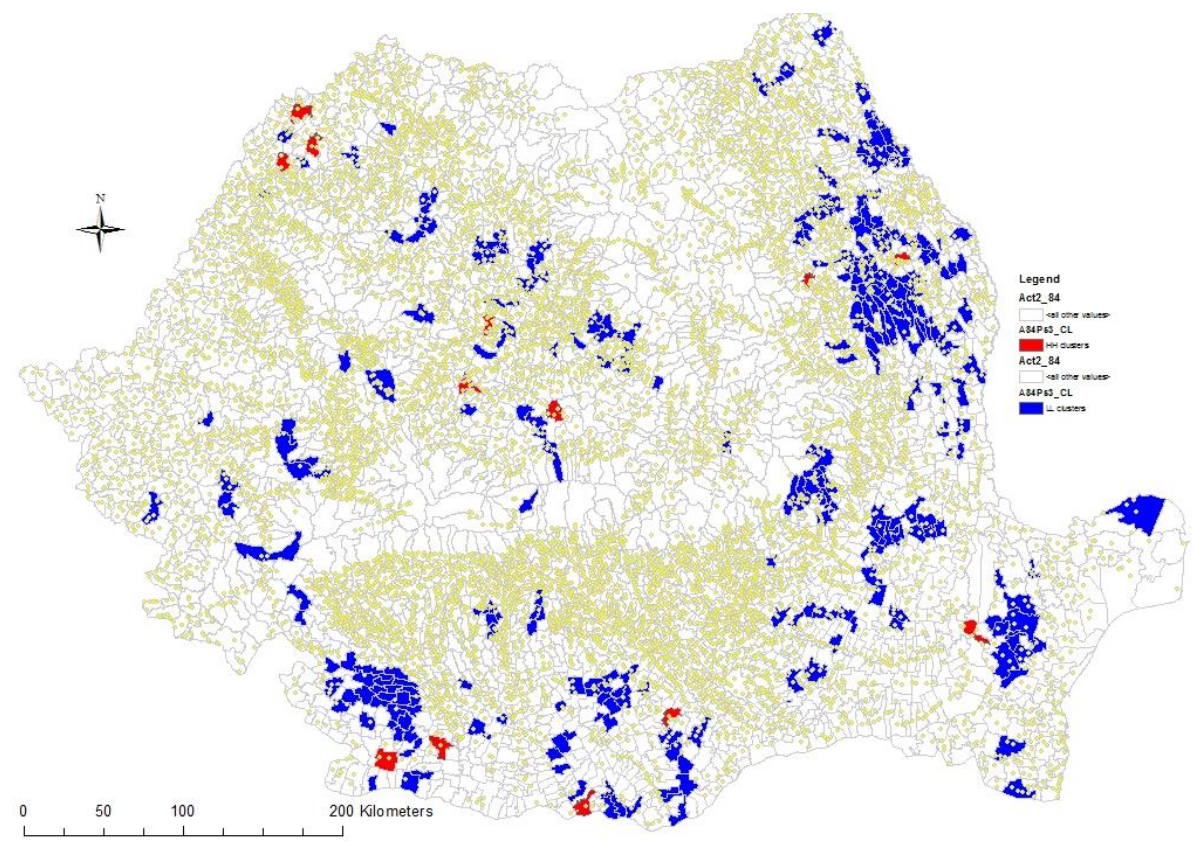

Fig.4. Map 2. The HH and LL clusters for the tertiary employees in public administration in 2011 (RPL data INS) and A: Locations with No State intervention in Broadband investment

Source: Map realized by authors in Arc GIS, using data from Arc Cloud, NUTS5/LAU2 shape file ESRI Romania Note: (World Bank 2017 Feature Layer, Territorial Observatory, MDRAP) at Lau2 level and villages 
The International Journal

ENTREPRENEURSHIP AND SUSTAINABILITY ISSUES

ISSN 2345-0282 (online) http://jssidoi.org/jesi/

2018 Volume 6 Number 2 (December)

http://doi.org/10.9770/jesi.2018.6.2(18)

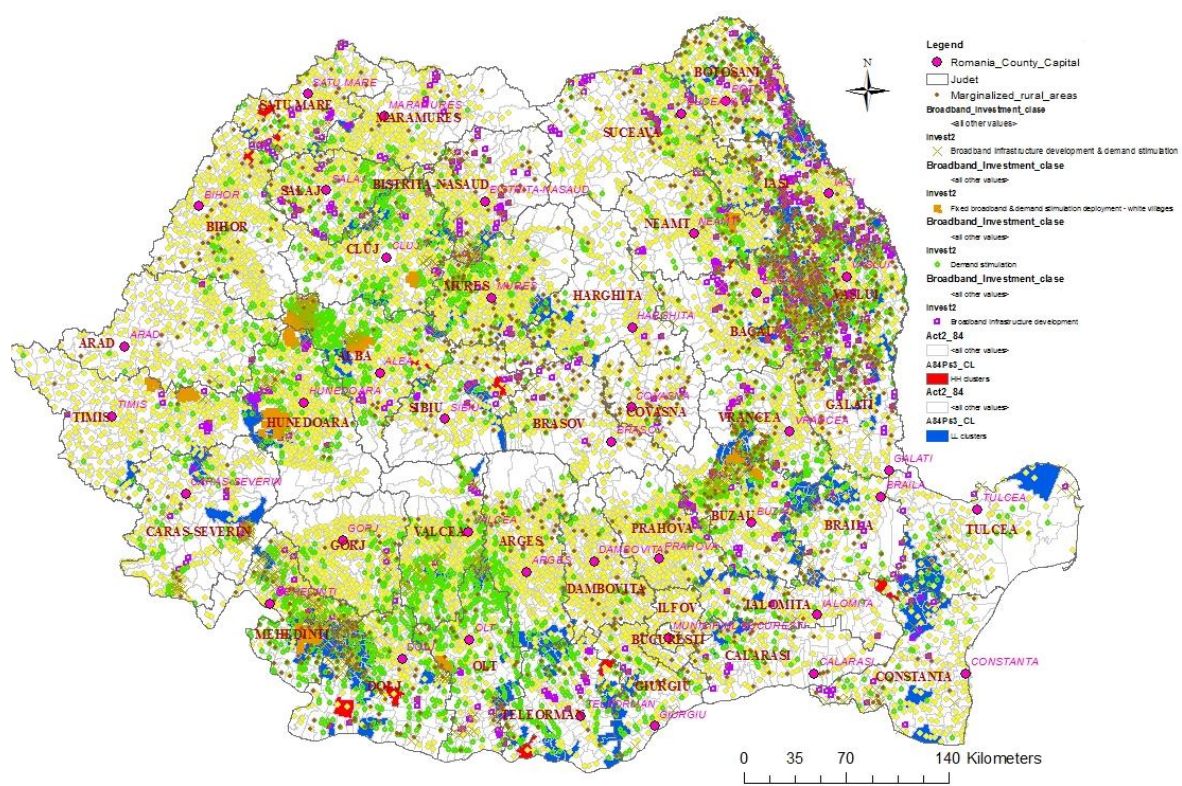

Fig.4. Map 2. The HH and LL clusters for the tertiary employees in public administration in 2011 (RPL data INS) and B: Typologies of Broadband investments and Marginalised rural areas

Source: Map realized by authors in Arc GIS, using data from Arc Cloud, NUTS5/LAU2 shape file ESRI Romania Note: (World Bank 2017 Feature Layer, Territorial Observatory, MDRAP) at Lau2 level and villages

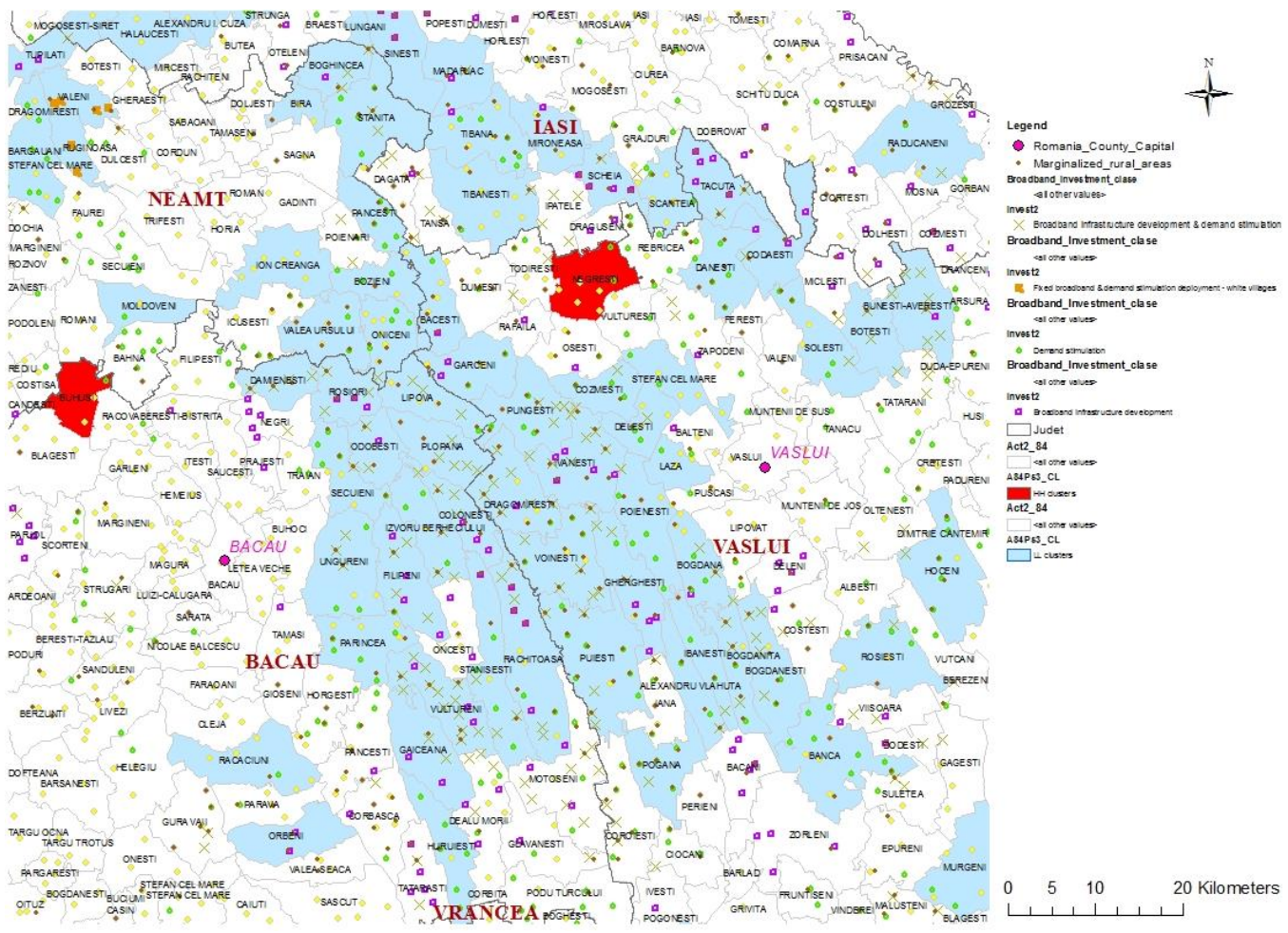

Fig. 5. Detail 1. Vaslui and Surroundings 
Source: Map realized by authors in Arc GIS, using data from Arc Cloud, NUTS5/LAU2 shape file ESRI Romania

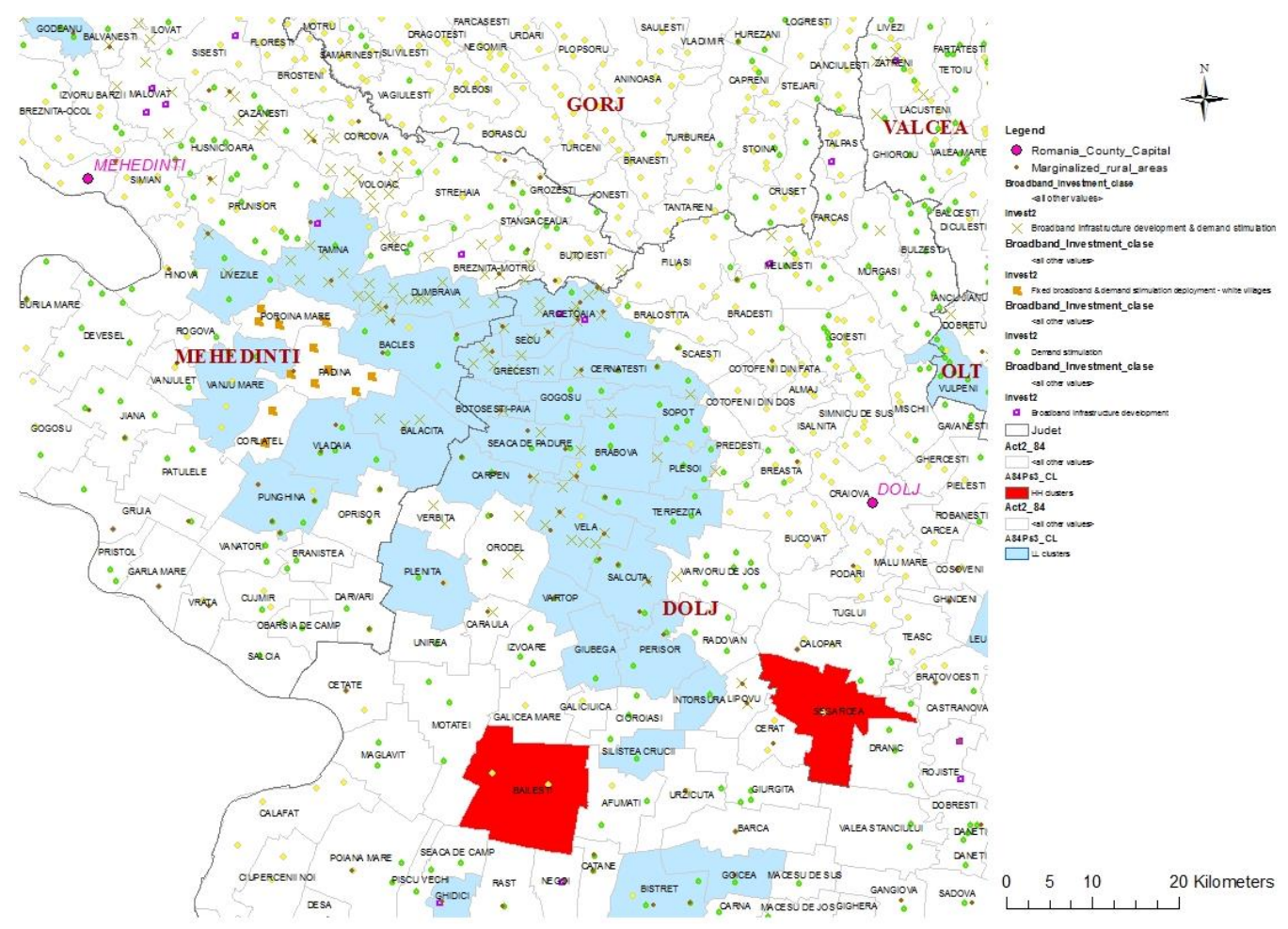

Fig. 6. Detail 2. Mehediți and Surroundings

Source: Map realized by authors in Arc GIS, using data from Arc Cloud, NUTS5/LAU2 shape file ESRI Romania

DiMaggio \& Hargittai (2001), arguments to look further the Internet penetration, transformation that induce new dimensions of inequalities - "digital inequality: in equipment, autonomy of use, skill, social support, and the purposes for which the technology is employed". The race to fill the digital gap is a shapeshifter while "the rapidity of organizational as well as technical change means that it is difficult to presume that current patterns of inequality will persist into the future"!

Dunleavy et.al. (2005) iterate as important uncertainities for Digital - Era Governance, among which the "Civil liberties groups critique data warehousing without adequate individual privacy rights, especially when such data is linked to ever more intrinsically personal identifiers, such as biometric data and genetic information".

\section{Conclusions}

In Romania, the high human capital in public services is spatially concentrate in couple hubs (see maps - red bullets), especially in urban areas with a broadband infrastructure coverage at the (best) European standards. (Figure 3. Map 1). On opposite side, we can observe the disparities in rural areas related to urban areas concerning the lack of high human capital (blue color shapes) in public administration and a poor broadband infrastructure, as well as an insufficient e-government development. It is visible, too, a wide dispersion of marginalized rural areas, 
where is a poor socio-economic development, a few public services and a weak broadband infrastructure (correlation with socio-economic indicators).

Broad band expansion priorities should be spatially correlated with the absence of high human capital in public administration. There is visible a spatial correlation between the LL clusters and marginalized location as well as low or absent broadband infrastructure coverage. Also, very important, at the county level is visible on the detailed maps the center periphery model, where the center is usually the county residence and the LL clusters are the frontier / boundaries of the counties - we could call them "no man's land". In other words is important to emphasize the broadband infrastructure employment multiplication effect as well as the presence of public administration services towards the population as a growth and development factor for each location.

In the digital innovation context should be relinked the public services with the population in the sense of helping and supporting the citizen not only in relation with the state but in view to solve citizen's individual problems.

Both Digital Agenda 2020 and the Administration strategy are strongly correlated together but are not harmonized with the high human capital policy, even if there are objectives strongly dependent by this category. The digital skills acquisition for the tertiary employees in public administration is a priority. To create and to sustain an innovative digital public services Romania needs to improve its profile distribution of employees' categories: more scientists, engineers and technicians. It's important also, to improve the human resources and the data management in order to implement the policy indicators and to respond proactively to the public.

The high human capital problem is a delicate one. In public administration the high human capital is clustered in a few innovative hubs which in the absence of a functional and interconnected national administration IT system. These objective conditions makes impossible the democratic governance act, especially on the context of regional decentralization. Considering that the human resource is finite, and more and more in deficit (especially by new digital skills profile) a solution could be the development of intelligent public services at distance in a customized way, tailored for the local problems (Brown, 2015).

In marginalized locations and especially in villages/communes where are made investments in broadband there should provide skills acquisition opportunities, correlated with the beneficiaries profile. A large part of these activities need to be managed in a coordinated and synchronic manner with the operationalization of the broad band expansion, by the Labor Ministry in active measures programs.

Not in the last the broadband infrastructure investment and operationalization in a functional manner is an instrument both for inclusion and increasing resilience of the community, mechanism to attract new investment.

Another direction, very important to be researched further in Romania, is the multiplication effect of the broadband infrastructure expansion and new jobs creation next to capital investment returns (multiplication effect) and the innovation potential increasing across the territory, transversal in socio-economic systems.

\section{References}

Anselin, L. (2003). GeoDa ${ }^{\mathrm{TM}} 0.9$ User's Guide, Spatial Analysis Laboratory, Department of Agricultural and Consumer Economics University of Illinois, Urbana-Champaign, Urbana, IL 61801, 2003. http://sal.agecon.uiuc.edu/ and Center for Spatially Integrated Social Science, http://www.csiss.org/, Revised, June 15, 2003, accessed on 2.02.2018 
Anselin, L. (2005). Exploring Spatial Data with GeoDaTM: A Workbook, Center for Spatially Integrated Social Science, Illinois, and U.S.A, 2005. Available from https://geodacenter.asu.edu/system/files/geodaworkbook.pdf, accessed on 2.02.2018

Anselin, L. (2016). GeoDA 1.8.1. GeoDA Workshop Part I, Center for Spatial Data Science, University of Chicago, 2016. Available from: https://spatial.uchicago.edu/, accessed on 2.02.2018

Bratu, V. (2018). Banca Mondială - oficial: Niciun progres de 6 luni în reformarea ANAF - discuții pentru închiderea proiectului, Curs de Guvernare, Available from http://cursdeguvernare.ro/banca-mondiala-oficial-niciun-progres-de-6-luni-reformarea-anaf.html, accessed on 5.03.2017

Brown, P. (2015). UK's Digital Inclusion Strategy aims to remove hurdles from e-Administration. Documentation, digital-by-default. Available from: https://joinup.ec.europa.eu/document/uks-digital-inclusion-strategy-aims-remove-hurdles-e-administration, accessed on 5.03.2017

DESI 2017: European Commission. (2017). Digital Economy and Society Index 2017 - Romania, Available at: https://ec.europa.eu/digitalsingle-market/en/news/digital-economy-and-society-index-desi-2017, accessed on 03.02.2018

Digital Agenda 2014-2020 for Romania. Available at: https://www.comunicatii.gov.ro/agenda-digitala-pentru-romania-2020/, accessed on 03.02.2018

Digital Economy and Society Index (2017) Available at: https://ec.europa.eu/digital-single-market/en/scoreboard/romania, accessed on 03.02.2018

Dunleavy, P., Margetts, H., Bastow,S., Tinkler, J. (2006). New Public Management Is Dead-Long Live Digital-Era Governance, Journal of Public Administration Research and Theory, 16(3), 1 July 2006, Pages 467-494, Available at: https://doi.org/10.1093/jopart/mui057, accessed on 2.26.2018

DiMaggio, P., Hargittai, E. (2001). From the 'Digital Divide' to 'Digital Inequality': Studying Internet Use as Penetration Increases, Available at: https://www.semanticscholar.org/paper/From-the-'-Digital-Divide-'-to-\%60-Digital-Inequality-DiMaggioHargittai/4843610b79d670136e3cdd12311f91f5cc98d2ee, accessed on 6.09.2018

EDPR.RO.2017: European Commission. (2017). Europe's Digital Progress Report (EDPR), 2017 Country Profile Romania, Available at: http://ec.europa.eu/newsroom/document.cfm?doc_id=44331, accessed on 03.02.2018

EDPR.RO.Telecom2017: European Commission, 2017. Europe's Digital Progress Report (2017), Available at: http://ec.europa.eu/newsroom/dae/document.cfm?doc_id=44464, accessed on 03.02.2018

European Commission (2017), European Semester Thematic Factsheet Quality of Public Administration, Available at: https://ec.europa.eu/info/sites/info/files/file_import/european-semester_thematic-factsheet_quality-public-administration_en.pdf, accessed on 03.02 .2018

Gasik, S., (2016). Are public projects different than projects in other sectors? Preliminary results of empirical research. Procedia Computer Science 100, 399-406 https://doi.org/10.1016/j.procs.2016.09.175 at: https://www.sciencedirect.com/science/article/pii/S1877050916323432, accessed on 2.26.2018

Gatman, A., 2011. e-Government - Assisting Reformed Public Administration in Romania. Available at: http://revecon.ro/articles/20111/2011-1-12.pdf, accessed on 3.04.2018

Indicele economiei și societății digitale, (2016) - profil de țară (Comisia Europeană, DG CONCT), (ro / en), Available at: https://www.comunicatii.gov.ro/agenda-digitala-pentru-romania-2020/, accessed on 03.03.2018

ITU 2017/I (2017) Measuring the Information Society Report 2017. Volume 1. International Telecommunication Union. Available at https://www.itu.int/en/ITU-D/Statistics/Documents/publications/misr2017/MISR2017_Volume1.pdf, accessed on 1.03.2018

ITU 2017/II (2017) Measuring the Information Society Report 2017. Voleme 2 International Telecommunication Union. Available at https://www.itu.int/en/ITU-D/Statistics/Documents/publications/misr2017/MISR2017_Volume1.pdf,accessed on 1.03.2018 
Krugman, P., Venables, A. J., Fujita, M. (1999). The Spatial Economy. Cities, Regions, and International Trade, The MIT Press Cambridge, Massachusetts London, England. 1999, Available at: http://geografi.ums.ac.id/ebook/The_Spatial_Economy-Fujita_Krugman_Venables.pdf, accessed on 02.02.2018

Malecki, E., J. (2003), Digital development in rural areas: potentials and pitfalls, Journal of Rural Studies 19 (2003) 201-214, Available at: https://doi.org/10.1016/S0743-0167(02)00068-2 , accessed on 6.09.2018

Minges, M. (2015) Exploring the Relationship between Broadband and Economic Growth Background, Paper prepared for the World Development Report 2016: Digital Dividends, World development Report, Available at: http://pubdocs.worldbank.org/en/391452529895999/WDR16-BP-Exploring-the-Relationship-between-Broadband-and-Economic-GrowthMinges.pdf, accessed on 28.02.2018

Moretti, E., Thulin, P. (2013). Local Multipliers and Human Capital in the United States and Sweden, Industrial and Corporate Change, 22(1), 339-362., Available at: https://academic.oup.com/icc/article/22/1/339/885578, accessed 10.02.2016

M\&E Manual (2017) Monitoring and Evaluation Manual for the The National Strategy regarding Digital Agenda for Romania 2020, the World Bank / Manualul de Monitorizare şi Evaluare a Strategiei Naţionale privind Agenda Digitală pentru România 2020, Banca Mondială, versiunea Ianuarie 2016, publicat la 29.01.2016, Available at:https://www.comunicatii.gov.ro//wpcontent/uploads/2016/02/Manual_Monitorizare_Evaluare_v2.0-BM.pdf,accessed on 1.03.2018

Pelinescu, E. (2015). The impact of human capital on economic growth, Procedia Economics and Finance 22, 184 - 190. Available at: http://www.sciencedirect.com/science/article/pii/S2212567115002580, accessed 10.06. 2017

Pelinescu, E. (2016). The human capital and development. The Romanian case study. 2nd International Conference on Recent Advances in Economic and Social Re-search May 12-13, 2016. Conference dedicated to the 150th anniversary of the Romanian Academy - organized by Institute for Economic Forecasting. p. 1-15. Available at: https://ideas.repec.org/p/rjr/wpconf/161105.html, accessed 10.06. 2017

Pelinescu, E., Crăciun, E. (2014). The human capital in the knowledge society. Theoretical and empirical approach. No. 20-2014, Manager-leadership between power temptation and efficiency, 7-18. Available at: https://ideas.repec.org/a/but/manage/v20y2014i1p7$\underline{18 . h t m l}$, accessed 10.06. 2017

Pelinescu, E., Iordan, M., Chilian, M.-N. (2011). Competitiveness of the Romanian economy from European perspective. Institute for Economic Forecasting, Romanian Academy "Nicolae Titulescu" University from Bucharest, Romania 1st Workshop on Modelling and Economic Forecast "New Trends in Modelling and Economic Forecast" 9-10 December 2011. Available at: https://ideas.repec.org/a/ntu/ntumef/vol1-iss1-12-086.html, accessed 10.06. 2017

Philip, L., Cottrill, C., Farrington, Williams, F., Ashmore, F. (2017). The digital divide: Patterns, policy and scenarios for connecting the 'final few' in rural communities across Great Britain, Journal of Rural Studies 54, $386-398 . \quad$ Available at: http://dx.doi.org/10.1016/j.jrurstud.2016.12.002, accessed on 3.04.2018

Revenue Administration Modernization Project (2017) Implementing agency Ministry of Economy \& Finance, Available at: http://projects.worldbank.org/P130202/romania-tax-modernization-project?lang=en\&tab=overview, accessed on 1.03 .2018

Roberts, E., Anderson, B.A, Skerrat, S., Farrington, J. (2017). A review of the rural-digital policy agenda from a community resilience perspective, Journal of Rural Studies 54, 372e385, Available at: http://dx.doi.org/10.1016/j.jrurstud.2016.03.001 3.04.2018

Ro-NET Project Documentation (2015) Available at: https://www.comunicatii.gov.ro/proiecte-in-implementare/proiectul-ro-net/,accessed on 1.03 .2018

SADR (2017) Strategia Națională privind Agenda Digitală pentru România 2020, versiunea aprobată, februarie 2015, Available at: https://www.comunicatii.gov.ro/agenda-digitala-pentru-romania-2020/, accessed on 2.03.2018

Seri, P., Zanfei, A. (2013). The co-evolution of ICT, skills and organization in public administrations: Evidence from new European country-level data. Structural Change and Economic Dynamics. 27, 160-176. available at: Available at: https://www.sciencedirect.com/science/article/pii/S0954349X13000507?via\%3Dihub, accessed on 2.26.2018 
The International Journal

ENTREPRENEURSHIP AND SUSTAINABILITY ISSUES

ISSN 2345-0282 (online) http://jssidoi.org/jesi/

2018 Volume 6 Number 2 (December)

http://doi.org/10.9770/jesi.2018.6.2(18)

SDG-9 (2017) HLFP Thematic Review of SDG-9: Build resilient infrastructure, promote inclusive and sustainable industrialization and foster innovation. A global perspective on SDG-9. High -Level Political Forum on Sustainable Development. Available at: https://sustainabledevelopment.un.org/content/documents/14363SDG9format-revOD.pdf, accessed on 2.03.2018

Shenglin, B., Simonelli, F., Uidong, Z., Bosc, R., Wenwei, L. (2017). Digital Infrastructure. Overcoming the Digital Divide in China and European Union, available at: https://core.ac.uk/download/pdf/148912266.pdf, accessed on 6.09.2018

Stroe, C., Cojanu, S. (2017). Profiles and Dynamics of In-Work Poverty in Romania. Economic and Social Development (Book of Proceedings), 26th International Scientific Conference on Economic and Social, p.129. Available at: https://www.researchgate.net/scientific-contributions/79291127_Cristina_Stroe , accessed on 03.20.2018

Vasilache, A. (2017). Proiectul RO-NET de 85 milioane de euro pentru informatizarea zonelor sarace din Romania, in atentia procurorilor DIICOT, Available at: https://economie.hotnews.ro/stiri-telecom-22056991-proiectul-net-85-milioane-euro-pentru-informatizarea-zonelorsarace-din-romania-atentia-procurorilor-diicot.htm, accessed on 3.04.2018

World Bank (2015b) Contributions to the elaboration of a National Strategy Project and Action Plan on Social Inclusion and Poverty Reduction 2015-2020 (section 3.2.1), Available at: http://www.mmuncii.ro/j33/images/Documente/Familie/2016/SF BancaMondiala EN web.pdf accessed on 1.03.2018

World Bank (2015) Raport privind tipologiile de comunităţi/zone geografice şi opţiunile pentru intervenţii investiţionale în reţele broadband şi NGN, prin Acordul de servicii de consultanţă privind asistenţa pentru implementarea Strategiei Naţionale privind Agenda Digitală pentru România 2014-2020, Banca Mondială, versiunea Noiembrie 2015, publicat la 29.03.2016, Available at: https://www.comunicatii.gov.ro/wp-content/uploads/2016/01/Raport-privind-tipologiile-de-comunit\%C4\%83\%C5\%A3i-zone-geografice$\%$ C5\%9Fi-op\%C5\%A3iunile-pentru-interven\%C5\%A3ii-investi\%C5\%A3ionale-\%C3\%AEn-re\%C5\%A3ele-broadband-\%C5\%9Fi-NGNBanca-Mondiala-nov.-2015.pdf, accessed on 2.03.2018

World Bank (2018) Implementation Status \& Results Report: Disclosable Version of the ISR - Revenue Administration Modernization Project - P130202 - Sequence No: 10 (English) from the date February 7, 2018, Available at: http://projects.worldbank.org/P130202/romania-tax-modernization-project?lang=en\&tab=documents\&subTab=projectDocuments, accessed on 03.03.2018

World Bank, 2015c, Report 2. Inventory of Broadband Areas in Romania. Available at: https://data.worldbank.org/country/romania, accessed on 1.03 .2018 
The International Journal

ENTREPRENEURSHIP AND SUSTAINABILITY ISSUES

ISSN 2345-0282 (online) http://jssidoi.org/jesi/

2018 Volume 6 Number 2 (December)

http://doi.org/10.9770/jesi.2018.6.2(18)

Short biographical note about the contributors at the end of the article (name, surname, academic title and scientific degree, duties, research interests):

Cristina LINCARU, is a PhD in Management, Senior Researcher at National Scientific Research Institute for Labour and Social Protection (INCSMPS). Currently is editor of HOLISTICA Journal of Business and Public Administration and Member in the Editorial Board E-Journal of International and Comparative LABOUR STUDIES, Member in The Board of the Hellenic Association of Regional Scientists H.A.R.S., Academic Member in ATINER, and Member in Mechatrec. She is a member in scientific association: The Romanian Regional Science Association, European Regional Science Association, The Regional Science Association International, and The Romanian Statistical Society - SRS Board member. Research interests: the new models of work, innovation, knowledge, the New Economic Geography, Evolutionary Economy, sustainability, development, and developing countries.

ORCID: https://orcid.org/0000-0001-6596-1820

Speranta PIRCIOG is since 2003 the Scientific Manager of the National Research Institute in the field of Labour and Social Protection of Romania (INCSMPS) where she works as a researcher (currently senior researcher 1st rank) since 1990. Pirciog Speranța is an economist by training and holds a Ph.D. in economics. She coordinated more than 50 projects on topics related to the labor market. Research interests: labour market, labour ecionomics, innovation in labour and social protection strategies and polices, sustainable development and quality of life.

ORCID: https://orcid.org/0000-0003-0215-038X

Adriana GRIGORESCU, Correspondent Member of Academy of Romanian Scientists, is Professor of Management and Marketing at the National University of Political Studies and Public Administration. The interest research area is interdisciplinary comparative and integrated studies on business and public sectors. General Director of Global Economy \& Governance Interdisciplinary Research platform is promoting academic and research networks and integrated, interdisciplinary studies. Author of papers, books and studies, managed or was part of over 30 national and international projects. Research interests: public and business management and marketing; entrepreneurship and regional development; sustainability of public and business environment.

ORCID: https://orcid.org/0000-0003-4212-6974

Gabriela TUDOSE is a senior researcher in "Labour market policies" Department of National Scientific Research Institute for Labour and Social Protection - INCSMPS, Bucharest. Due to her interdisciplinary educational background she developed research work in a large spectrum of the labour market. Her $\mathrm{PhD}$ thesis is focused on skill management analysis in a spatial view and central research interests are: human resources management, knowledge management, and assessment of active labour market policies, spatial analysis of labour market indicators, R\&D activity, innovation and quality of work in small firms.

ORCID: https://orcid.org/0000-0002-3540-9987 
The International Journal

ENTREPRENEURSHIP AND SUSTAINABILITY ISSUES

ISSN 2345-0282 (online) http://jssidoi.org/jesi/

2018 Volume 6 Number 2 (December)

http://doi.org/10.9770/jesi.2018.6.2(18)

\section{Annex 1}

Table A. Detailed content of the activities included in Public administration and defence; compulsory social security according to The International Standard Industrial Classification of All Economic Activities ISIC Rev.4 code 84

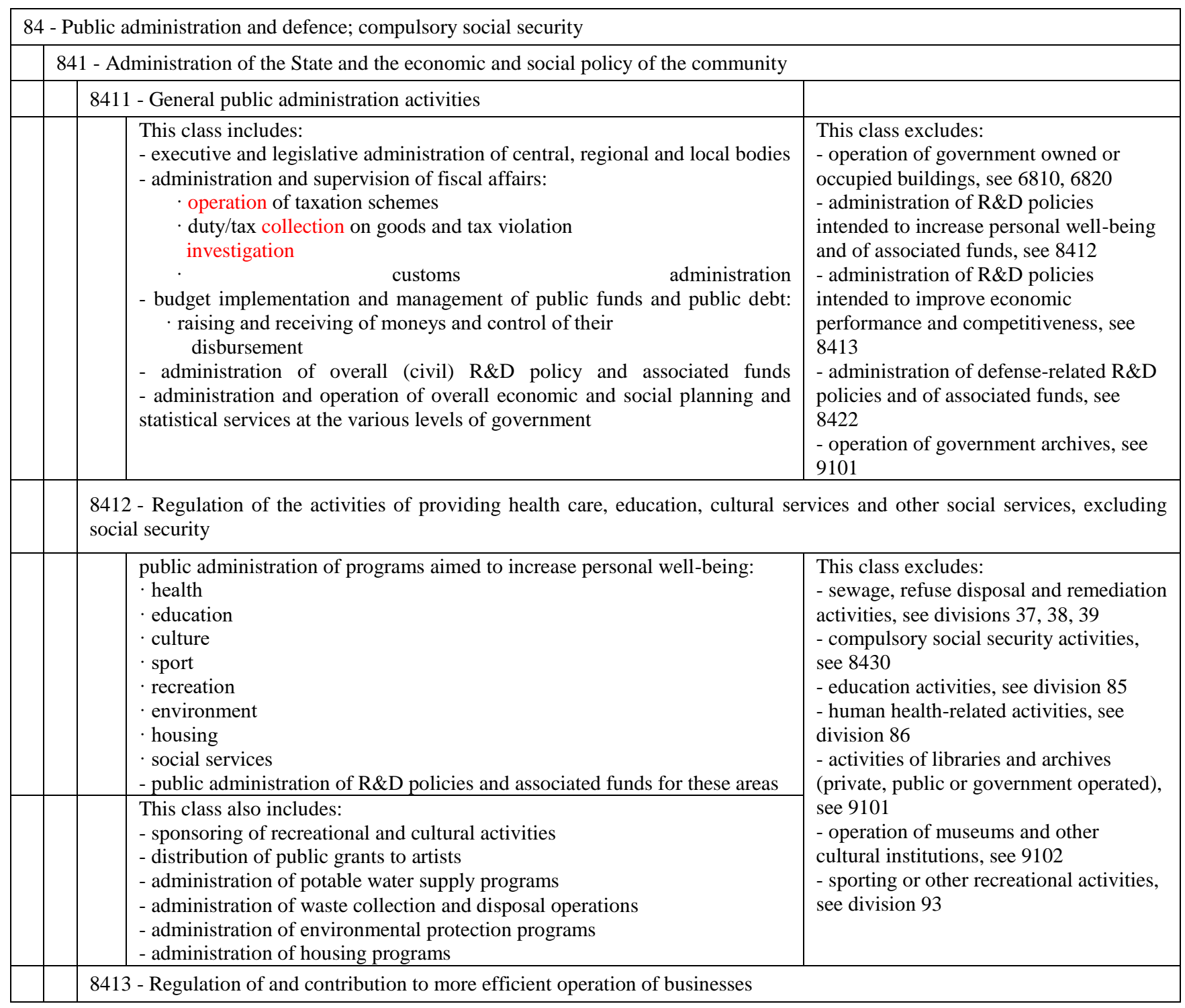


The International Journal

ENTREPRENEURSHIP AND SUSTAINABILITY ISSUES

ISSN 2345-0282 (online) http://jssidoi.org/jesi/

2018 Volume 6 Number 2 (December)

http://doi.org/10.9770/jesi.2018.6.2(18)

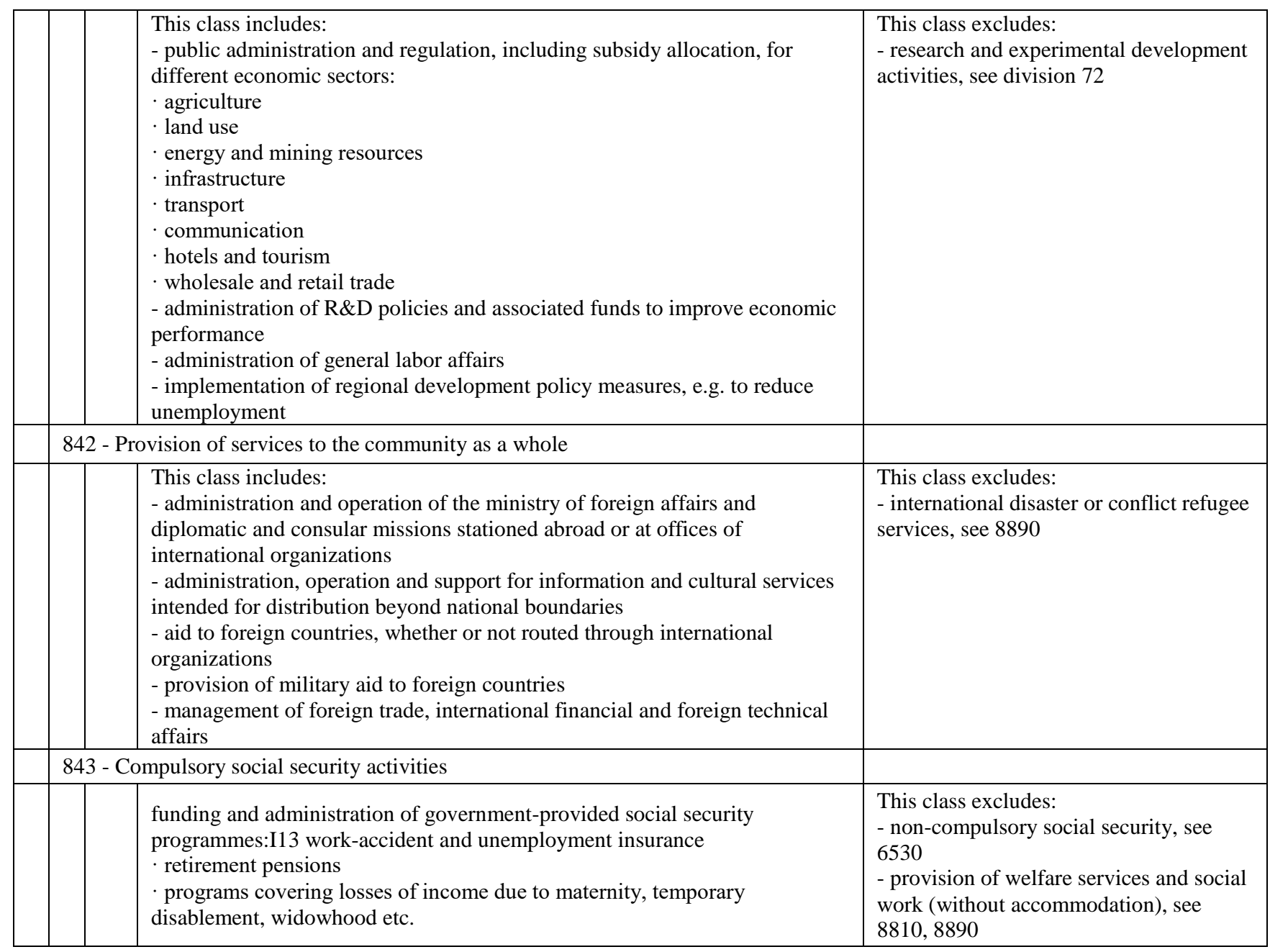

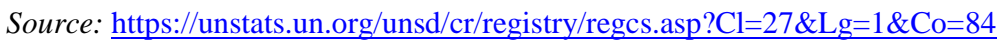

Note: These economic activities are subdivided in a hierarchical, four-level structure of mutually exclusive categories, facilitating data collection, presentation and analysis at detailed levels of the economy in an internationally comparable, standardized way. Source: https://unstats.un.org/unsd/EconStatKB/KnowledgebaseArticle10132.aspx

Table B. ICT ranking and value in 2017 and 2016

\begin{tabular}{|c|c|c|c|c|c|c|c|c|c|}
\hline & $\begin{array}{c}\text { (Global) } \\
\text { Rank } \\
2017\end{array}$ & $\begin{array}{c}\text { Ro } \\
\text { IDI } \\
2017 \\
\end{array}$ & $\begin{array}{c}\text { EU } 40 \\
\text { IDI } 2017\end{array}$ & $\begin{array}{l}\text { Rank } \\
2016\end{array}$ & $\begin{array}{c}\text { IDI } \\
2016\end{array}$ & $\begin{array}{c}\text { EU } 40 \\
\text { IDI } \\
2016 \\
\end{array}$ & $\begin{array}{c}\mathrm{d} 2017- \\
2016\end{array}$ & $\begin{array}{c}\text { regional } \\
\text { Rank } 2017 \\
\text { (Europe) }\end{array}$ & $\begin{array}{c}\text { regional } \\
\text { Rank } 2016 \\
\text { (Europe) }\end{array}$ \\
\hline IDI & $58 / 176$ & 6.48 & 7.5 & $61 / 175$ & 6.23 & 7.34 & 0.25 & $35 / 40$ & $36 / 40$ \\
\hline access & 60 & 6.98 & 7.8 & 60 & 6.8 & 7.73 & 0.18 & & \\
\hline use & 61 & 5.59 & 6.94 & 66 & 5.08 & 6.62 & 0.51 & & \\
\hline skill & 60 & 7.25 & 8.02 & 51 & 7.37 & 7.97 & -0.12 & & \\
\hline
\end{tabular}

Source: ITU 2017/I, p84 
Table C. Key indicators for Romania (2016)

\begin{tabular}{|l|l|l|l|}
\hline Key indicators for Romania (2016) & Romania & Europe & World \\
\hline Fixed-telephone sub. per 100 inhab. & 19.1 & 37.7 & 13.6 \\
\hline Mobile-cellular sub. per 100 inhab. & 106.4 & 118 & 101.5 \\
\hline Fixed-broadband sub. per 100 inhab. & 20.7 & 30.2 & 12.4 \\
\hline Active mobile-broadband sub. per 100 inhab. & 73.7 & 80.1 & 52.2 \\
\hline 3G coverage (\% of population) & 99.9 & 98.5 & 85 \\
\hline LTE/WiMAX coverage (\% of population) & 75.2 & 92.2 & 66.5 \\
\hline Mobile-cellular prices (\% GNI pc) & 0.7 & 1 & 5.2 \\
\hline Fixed-broadband prices (\% GNI pc) & 0.9 & 1.2 & 13.9 \\
\hline Mobile-broadband prices 500 MB (\% GNI pc) & 0.2 & 0.6 & 3.7 \\
\hline Mobile-broadband prices 1 GB (\% GNI pc) & 0.5 & 0.6 & 6.8 \\
\hline Percentage of households with computer & 74 & 79.6 & 46.6 \\
\hline Percentage of households with Internet access & 72.4 & 82.5 & 51.5 \\
\hline Percentage of individuals using the Internet & 59.5 & 77.9 & 45.9 \\
\hline Int. Internet bandwidth per Internet user (kbit/s) & 155.5 & 178 & 74.5 \\
\hline
\end{tabular}

Source: ITU 2017/II, p.152 